\title{
Historias de vida sobre el liderazgo, una lectura de la guerra y la paz
}

$\mathrm{D}$ ado el propósito de esta investigación, este espacio fue ubicado para que protagonistas de la guerra y la discriminación en Colombia nos ofrecieran un breve relato de su vida en la construcción de la paz desde abajo. Según esto, se registran cuatro tipos de acción de liderazgo:

- El primer líder narra su acción en los pueblos indígenas, y da un ejemplo de construcción de un cabildo en la capital, como respuesta al desplazamiento que produjo el conflicto armado sobre el pueblo Pijao, pues se apostó por la unidad, la memoria y la identidad.

- La segunda líder ubica su actividad en las negritudes del Pacífico colombiano, donde su vida personal y colectiva la condujo a su labor en la construcción de la paz en el Pos-acuerdo de manera directa con el gobierno colombiano.

- La tercera líder, es una mujer que desde su niñez vivió la guerra, pero nunca perdió la esperanza política como posibilidad de paz en la labor de liderazgo de su padre, lo que la llevó a ella, a su 
madre y a sus hermanos a vivir una historia frente al conflicto armado y la persecución de la izquierda en Colombia, lo que los condujo a perder a su padre, cuyo legado defiende y empodera mediante su liderazgo en la construcción de la memoria colectiva como punto de partida para la comprensión de la paz.

- Finalmente, el cuarto líder es un abogado que ha sido durante toda su vida un activista en el litigio jurídico, lo que le permitió a la comunidad LGBTI transformar estructuralmente el escenario político y jurídico para afirmar los derechos como respuesta a los escenarios de exclusión social.

En este sentido, este capítulo es de autoría de estos líderes porque se trata de su historia de vida que se narra aquí, a pesar de que se elaboró a partir de una entrevista, no se escribió la narración en el sentido de pregunta y respuesta con el fin de que los lectores pudieran tener una lectura más fluida de la vida de estos líderes, con quienes se logró una cercanía sobre la comprensión de lo que significa ser líder, representar un movimiento, defender los derechos humanos y ser un ciudadano que busca construir la paz desde abajo. 


\section{Historia de vida de Marco Tulio Yate Yara contada por él mismo}

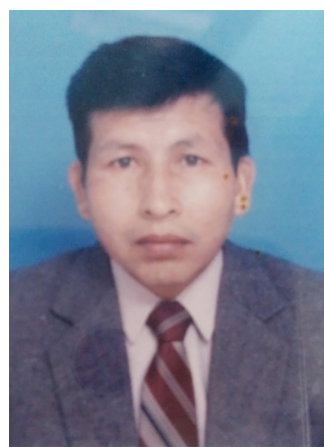

"Un indígena no se reconoce por sus rasgos, se reconoce por la capacidad y el empoderamiento de la sabiduría ancestral”.

\section{MARCO TULIO YATE YARA}

\section{$\mathrm{M}$} i nombre es Marco Tulio Yate Yara, mi origen se encuentra en el municipio de Coyaima, Sur del Tolima, cuna ancestral Pijao. Mi padre se llamó Gavino Yate y mi madre Alejandra Yara, tengo nueve hermanos, todos con vida, son seis mujeres mayores y tres hombres menores, entre estos yo soy el mayor. Mi niñez fue en la vereda del Socorro donde hice la primaria en la escuela rural "Los Guayabos". Mi padre fue agricultor y también realizó obra social como líder, él se encargaba de concertar la intervención del municipio y de la vereda, esto lo hizo durante toda su vida. Falleció a los 65 años. Estudió primaria y, a pesar de ello, se desempeñó en trabajos de ingeniería civil, y en la repartición de fincas, como conciliador en sucesiones.

Mi madre se dedicó a las labores del hogar, ella falleció a los 58 años. En su labor, también apoyó a mi padre durante los procesos de organización gastronómica de la Comunidad. Allí existe "El Combite" que aún se practica, es algo parecido o equivalente a la minga. En este, participan los miembros de la comunidad y se apoya a las familias. Cada uno debe llevar algo para aportar para el almuerzo, ya sea un plátano, alguna cosa. En el combite, se realizan trabajos comunitarios, como el arreglo de vías, la construcción de escuelas o apoyar a alguna 
familia que esté en una situación difícil. La frecuencia del combite es de acuerdo con las necesidades, tanto de los trabajos comunitarios como del beneficio de la familia que le ayude a superar la necesidad.

La violencia que se vivió en mi pueblo fue la violencia bipartidista en el Tolima de donde surgieron varios grupos, la vereda era Liberal por lo que se presentaron alianzas entre los núcleos familiares que buscaron la defensa de descendientes ancestrales que provenían de Purificación, mientras que los vecinos de la etnia Pijao eran del otro partido, conservadores. Este conflicto produjo la necesidad de migrar. Cuando llegaban a atacar, debíamos desplazarnos a los montes, a los platanales o a la orilla del río, salíamos todos en conjunto con el fin de evitar las masacres.

Las marcas de la violencia se presentaron sobre todo en familias que las aniquilaron todas o que solamente quedaron con vida los niños, que tuvieron que afrontar la muerte de su núcleo familiar, o que se dispersó, viviendo el abandono del Estado, la pobreza, lo que produjo la migración de la etnia hasta la fecha. Igualmente, se vivió la violencia del Estado por militares del ejército y de la política misma. Los Pijaos, en su historia, siempre han sido nómadas por lo que avanzaron en su territorio, migrando hacia el Sur del Tolima, y también al Centro, yendo hasta la zona cafetera, lo que explica que exista un municipio con nombre Pijao en Quindío. Este nombre se debe a que lo fundaron los españoles que se enfrentaron a resguardos Pijaos. Durante mi adolescencia, recibí el apoyo de mi familia y me dediqué a acompañar el trabajo de mi padre, que era un líder muy reconocido, fue un periodo de aprendizaje

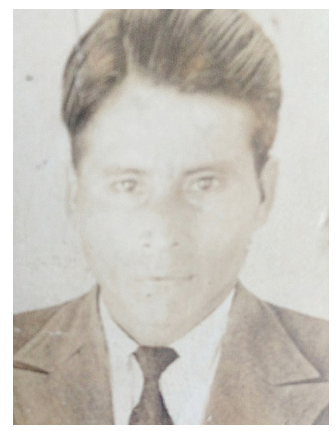


de las labores de conciliación en la vereda, y también llegaban familias que provenían de Coyaima y Chaparral, donde conocían su labor. Este fue el camino que me trazó, sin él no lo hubiera alcanzado.

Luego, entré al ejército donde presté servicio militar por obligación. En ese momento no había la exención de prestar el servicio militar para los pueblos indígenas como existe hoy en día. Allí pude conocer a los Wuayues en la Guajira y también a los Emberas, por lo que hice parte del grupo elite de inteligencia militar que en los ochenta, de la siembra de marihuana, se dio lugar al surgimiento del Narcotráfico. Mi función fue hacer contrainteligencia con los indígenas pero la barrera era el idioma, ya que el wayuú no hablaba el español solo hablaba wayinaike, creo que se llama así.

Me ubiqué en Nazaret, en la Alta Guajira, donde había una Congregación de Jesuitas que se encargaban de reclutar a todos los niños de las comunidades para enseñarles español que era la barrera para la inteligencia militar. Además, la congregación de origen italiano tenía como límite la lengua española, ya que no la dominaban muy bien. Hice parte de la escuela durante seis meses, enseñando español. Yo tenía 18 años cuando hice parte de este proceso, ya que por ser indígena, por mis rasgos, mis costumbres que eran parecidas, ellos depositaban la confianza en otros indígenas. El indígena en general es hermético y al encontrar otro indígena deja de serlo, se buscó forjar la confianza en los procesos de asimilación del aprendizaje del español. Mi trabajo fue ante todo de alfabetizador, de este modo se podía hacer la inteligencia, ubicando a los grupos del narcotráfico de la región.

Durante este periodo viví la discriminación por ser indígena, aún todavía. Yo comprendo que hay una diferencia entre ser indio y ser indígena. Ser indígena es una persona que tiene una sabiduría, una cultura y un conocimiento, mientras que indio es cualquiera. Ser indígena es quien se sienta en un escenario a demostrar la otra cara de lo que la mayoría de la gente del común piensa.

Duré cuatro años en el ejército, esto marcó mi vida porque cuando regresé el núcleo de mi familia no estaba completo. Nuestra familia no era de estrato alto pero tampoco pasábamos calamidades, ya que con el conocimiento de mi padre podíamos conseguir lo básico (conocimiento en relación con la naturaleza y en los procesos de conciliación). 
Al salir del ejército fue difícil enfrentar la vida, ya que al regresar fue complicado, quedé desamparado. Al llegar, enfrenté la vida de vuelta a mi territorio que fue aún más difícil por las condiciones de abandono del Estado, no hubo la posibilidad de pensar en forjar un futuro.

Mi padre consideraba que el progreso de los seres humanos estaba basado en el estudio y en el conocimiento de cada quien. Esto lo pude ver al analizar la vida, al emigrar a Bogotá. Durante seis meses, antes de llegar a la capital, viví con mis hermanas, pero sin embargo tuve un apoyo superficial, ya que cada una tenía su familia, y así es, cada uno tiene que hacer su propia familia y luchar por sus sueños. Mi sueño es lograr el liderazgo que mi padre me enseñó con el conocimiento ancestral y el conocimiento occidental, cuya finalidad era constituir argumentos para luchar por los derechos de los pueblos, cuando no se hablaba de pueblos.

Llegué a Bogotá a la edad de 21 años donde una hermana, allí hice el bachillerato, fue particular porque en este lugar pudimos iniciar con la conformación del cabildo indígena en Bogotá, ya que allí me encontré con miembros de la comunidad que llegaron a Bogotá en las mismas condiciones del desplazamiento con ocasión de la violencia y de la pobreza, ambas como consecuencia de los problemas que el bipartidismo dejó en la región.

En el año 2006, debido al recorrido de la vida y a lo que aprendí de mi padre, pude tener un conocimiento sobre ser líder, siendo líder en la ciudad no en mi territorio, lo que es una cosa distinta, esto me permitió organizar el Cabildo en Bogotá empleando el contenido de la Constitución de 1991. Nuestra etnia no participó en la construcción de la Constitución de 1991 fueron otras personas que en mi concepto no fueron las adecuadas para mostrar el liderazgo, marcando un beneficio de la etnia a la que pertenecían, no la construcción del Estado como país multiétnico que alberga a muchísimas comunidades indígenas.

Fue en Bogotá donde se reconocieron cinco pueblos indígenas hasta la fecha, pero faltan por reconocer a veinte etnias, lo que indica el abandono del Estado. Es el caso de los Embera que vienen del Chocó, son los que vemos en los puentes mendigando, ellos no han sido reconocidos, han sido abandonados por el Estado y han tenido que huir de la violencia. 
El abogado indígena, Rojas Birry participó en la Constitución del 91, lo único que teníamos antes era la ley 89 de 1890, la ley de Quintín Lame, pero allí no se le daba participación al indígena. Desde 1991, los indígenas empiezan a tener participación en todos los espacios, condiciones de garantía y participación, en lo político, en el Congreso y los Consejos, y en lo económico, en la creación de resguardos indígenas con apoyo económico para las comunidades. Sin embargo, en esto se olvida algo y es la crítica que tengo: al ser humano no se le debe dar el pescado sino enseñarle a pescar. No se le enseña, no se le apoya con tecnología en las faenas agrícolas, lo que mantiene su condición de pobreza.

La organización de los Pijao fue en el año 2000. Iniciamos cuatro familias y hoy somos 444 familias, era algo insólito tanto pensar en un pueblo indígena reconocido en la ciudad. Este proyecto lo desarrollé con el apoyo de un paisa, Dollman Zapata, un no indígena, esposo de una indígena. Con él, nos sentábamos a reflexionar sobre los derechos en la Constitución de 1991, pensábamos que donde haya una congregación indígena se debía reconocer un cabildo y a este debía apoyarlo el Distrito o el Municipio.

Traerlo de la provincia a la capital era insólito, salimos a ubicar descendientes pijaos radicados en Bogotá, ya que la exigencia era mínimo de 50 familias registradas. Es por ello que salíamos a parques a mirar rasgos de nuestra etnia, eso era algo complicado porque algunos querían formar un Cabildo y otros no. Mientras no se tenga pleno conocimiento de los derechos, no se va a lograr. Es necesario reconocer la sabiduría ancestral de los valores y fundamentos, del respeto por el otro, por el escuchar la opinión del que está al lado, así como la respuesta, si no, esta se vuelve unilateral.

Entre 2000 y 2005, logramos conformar un grupo de 82 familias con las que hicimos un censo y lo presentamos al Ministerio del Interior, luchamos por ese reconocimiento, algo impensable y lejano. Las primeras propuestas de reconocimiento fueron descabelladas. En la capital, era difícil el compromiso que debía asumir el Distrito sobre los pueblos indígenas que participaran en un Cabildo. En este proceso, nos reencontramos con otros pueblos: Muiscas de Suba y Bosa, Quichuas-ecuatorianos, Ingas del Valle del Guamués, con quienes 
teníamos la misma aspiración del reconocimiento. Finalmente, la respuesta del Ministerio del Interior fue incrédula, era algo insólito proponer un reconocimiento. La doctora Luz Elena Izquierdo, que estaba al frente del Ministerio del Interior de descendencia de los Arahuacos, provenientes de la Sierra Nevada, madre de la concejal de Bogotá, Atikigua, fue la que nos respaldó.

Los descendientes indígenas marginados de este espacio vieron la oportunidad de lograrlo por lo que llegaron a postularse. Eso fue algo insólito, sin embargo "Ati" dijo que le consultaría a los "Mamos" de la Sierra Nevada que son quienes manejan las cosas trascendentales, son los sabios. Ellos respondieron que sí lo hicieran, que era algo conveniente, que no generaba ningún perjuicio para el espacio que ella ocupaba. Se dio entonces el reconocimiento de cinco pueblos con el aval del Ministerio del Interior, llevándolo al Distrito. Allí fue otra lucha, los pueblos reconocidos exigían derechos diferenciales de los particulares, pero encontraron otra barrera: el desconocimiento total de los derechos de los pueblos indígenas, de la reforma constitucional de 1991 por el Estado, tanto como en la atención en salud y educación para superar las condiciones de extrema pobreza. En la actualidad, se vive esta situación, a muchas partes donde se llega se emplea es a partir de cuotas particulares y a su vez en cada cambio de periodo llega otro que desconoce los derechos de los indígenas como Pueblo. Entonces, toca estar ahí todo el tiempo recordándolo.

En 2005, bajo la alcaldía de Luis Eduardo Garzón, se desarrollaron varias reuniones en condiciones de inseguridad alimentaria que vivían los pueblos reconocidos como cabildos en Bogotá. Por lo que creamos el programa de "Apoyo Alimentario". De ahí, nace la propuesta de un almuerzo para cada uno de los miembros de cada cabildo reconocido. Esto no aplicaba a los Pijao en Bogotá, ya que este pueblo se encuentra ubicado en las 20 localidades. Era algo complejo, andar con un camión repartiendo a las 20 localidades o que todos fueran a la sede del cabildo que queda en Usme, en el barrio Alfonso López. Sin embargo, se hizo una contrapropuesta y era que la Secretaria de Integración Social cambiara los almuerzos por una canasta nutricional, donde los productos correspondieran con los usos y costumbres de cada pueblo, en el caso de los Pijao, el maíz y el plátano. 
Se conformaron unas canastas nutricionales y nacen como proyectos para el beneficio de cada pueblo, de acuerdo con la cantidad de miembros del núcleo familiar y, a su vez, se buscaba que fuera rotativo, este era el compromiso; familias que superaran la condición de extrema pobreza le entregaba el cupo a otra. En total se lograron 82 cupos de familias, divididas en categorías A, B, y C: A correspondía a familias de 1 a 3 miembros, B a familias de 3 a 5 miembros, y $\mathrm{C}$ a familias de 6 miembros en adelante. En la actualidad, se tienen 444 familias en el Cabildo y no todas reciben, porque se pide que uno de los productos sea donado por cada familia, formando así otros mercados para las familias restantes.

En materia de educación, hemos tenido avances pero no logros significativos, hay por ejemplo una carencia en el acceso a la Universidad. Creo que no deben someternos como todos a participar por un espacio. Los líderes deben verificar quién tiene la capacidad, porque no todos la tienen, para que puedan respaldar en el futuro a la comunidad con el conocimiento occidental, sin olvidar el conocimiento ancestral.

En el caso de la Salud, tampoco ha sido mucho el avance, se ha elaborado una propuesta para hospitales locales donde se alterne la medicina tradicional con la medicina occidental, proceso en el que no ha habido la verdadera participación de los indígenas.

En el ámbito artesanal, hay una carencia de participación de los indígenas en el apoyo, solo de vez en cuando abren un parque artesanal, pero no ha habido un empoderamiento distrital y estatal que nos permita comercializar nuestras artesanías sin intermediarios, lo que mejoraría nuestro sustento.

En el escenario religioso, es una parte personal de cada pueblo, de permanente contacto con el territorio. En mi caso personal contribuyo en el Resguardo con talleres de capacitación donde se busca llegar a los beneficios de cada pueblo, así como a los derechos de los pueblos indígenas.

En nuestra comunidad, se encuentran los ancianos, quienes mantienen parte de la lengua y sabiduría en todos los entes, desde la medicina hasta la gastronomía, son quienes representan nuestra cosmovisión. Por eso, sobre nuestra lengua se está en recopilación de lo que queda. Los Pijaos somos uno de los pueblos más guerreros que tuvo que enfrentar 


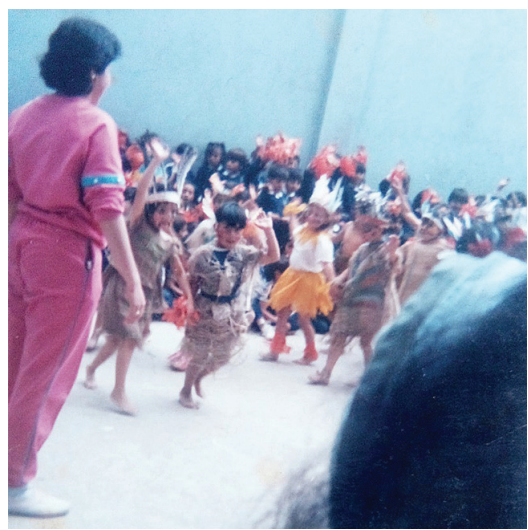

Grupo de danza infantil del Cabildo Indígena Pijao en Bogotá, D. C.

el conquistador, nunca se sometió al hombre blanco. El conquistador empleó armas letales con el fin de aniquilar la lengua del Pueblo, afirmaron que quien siguiera practicándola y no admitiera el español se le cortaba la lengua. Ellos preferían suicidarse antes que someterse.

Es que el reconocimiento es la base de la comunicación directa de cada etnia, pero en los Pijaos no es que todo esté perdido. En Coyaima, se encuentran palabras ancestrales todavía, por lo que se aplica la recopilación. De nuestra lengua puedo narrar algo que hace parte de nuestra cosmovisión y es el origen de los Pijao:

Hace muchos años, el mundo era solo una laguna donde no había espacio para la tierra, todo cubierto de agua, entonces TÁ (Sol), al ver el mundo lleno de agua, pensó que no tenía espacio donde descansar y llamó a su regidor CHAJUÀ (Calor), quien penetró al fondo de la laguna y evaporo parte del agua, TAIBA (Luna) se puso celosa porque ella representa a la mujer, ella quería que el mundo lleno de agua fuera un espejo para contemplar su figura todos los días. TÁ (Sol) al ver rechazada su propuesta de tener tierra firme, prometió vengarse y continuó evaporando las aguas hasta el día de hoy. TAIBA (Luna) reunió a CHIRÍ (Frío) y a CHAJUÁ (Calor), de ahí nace la vida que en la convicción del pueblo Pijao son los reguladores de la vida de todos los seres humanos. CHAJUÁ evaporó gran cantidad de agua, de ahí se originaron los primeros territorios de sus líderes, que son las zonas ancestrales de los Pijaos, son los primeros territorios sólidos: Coyaima, Calarma (cerca a Chaparral), Natagaima y Ortega. Aparece 
el frío y el calor que da paso a los primeros pijaos, esta es la cosmovisión como pueblo.

En nuestra concepción de Justicia, está la legislación indígena que es la justicia propia, la misma constitución lo dice, se debe trabajar alternando la justicia ordinaria en la comisión de delitos por parte de la comunidad. Yo fui Juez de Paz entre 2007 y 2011. Allí, tenía que tener conocimiento de la justicia ordinaria y de la justicia ancestral. $\mathrm{Me}$ encargaba de interpretarla equitativamente. El principio básico era ser juez neutral en el reconocimiento de derechos porque en algunos casos, los indígenas, cuando cometen delitos contra el blanco, se acogen a la justicia ancestral y no a la ordinaria, llegando a resguardarse en el territorio ancestral. Conocí varios casos de homicidio en los que ocurría esto.

Durante este manejo, la gente llegaba con la idea de que si me castiga la etnia como miembro va a ser menos severo el castigo. Ya que nosotros tenemos como castigo "El Fuete" que significa saneamiento y compromiso. Fuetazos significa reconocer el error. El saneamiento es espiritual ya que cuando se comete algún delito quiere decir que la persona no se encuentra bien. Entonces, requiere de un proceso de limpieza, de concientización, de sensibilizarlos sobre el error cometido que no se debe cometer. Compromiso que debe resarcir con la familia que ha afectado. En el caso de un homicidio, un indígena que mató a un miembro cabeza de familia ha dejado afectada y abandonada a una familia, por lo que debe hacerse material y espiritualmente del rol y cargo que desempeñaba el miembro cabeza de familia.

Cuando una persona recae en delitos se buscan alternativas. Como no tenemos cárcel en los cabildos ni en los resguardos, buscamos acuerdos con la justicia ordinaria, con el Distrito, para que por medio de sentencia lo lleven a un espacio carcelario. También conocí casos de inasistencia alimentaria y violencia intrafamiliar entre miembros de la etnia sobre todo por prácticas de machismo.

Ahora es necesario resaltar el conflicto moderno, diferente del conflicto bipartidista. Este afecta a los pueblos indígenas por el reclutamiento forzado, el desplazamiento y el sometimiento e incluso a la esclavitud por las Farc. Sometimiento con armas, aniquilamiento total. En los censos personales que hemos realizado, hemos encontrado que, 
a la edad en que pueden ser militares, se produce el reclutamiento y los llevan a la guerra. Terminamos siendo víctimas del reclutamiento porque les inculcan cosas diferentes y cuando vuelven al territorio llegan con condiciones de rebeldía, de dominación, de violencia. A nosotros los Pijao no nos interesa la guerra, ni los partidos. Para nosotros vivir bien es vivir en paz. Es una guerra que no beneficia a nadie y mucho menos a nosotros.

Existen casos de muchas maneras, las personas sometidas les cambia la mentalidad de ser indígenas, asumen una mentalidad diferente de guerra y violación, por lo que cambiar la etapa de la juventud que fue de sometimiento y no por voluntad la participación en la guerra. La dificultad que se tiene es la vida, vivirla es duro y complicado. A esta edad, los marca para toda la vida, cuando se tienen niñas violadas o muchachos que sufrieron los atropellos de la guerra, siempre queda en sus vidas. Esto afecta al pueblo, eso no es bueno para la comunidad porque es descarriarse de sus principios y su estructura étnica. Es necesaria la reflexión por el respeto por las personas, por las cosas, por uno mismo.

De esto queda que nunca nos llamaron a ser parte del Acuerdo de paz. Solo los políticos se acercan en periodos de elecciones que en el ámbito de la ciudad lo ven como necesario establecer lazos de comunicación con los pueblos para lograr algo. Y en nuestro caso, cuando queremos hacer algo político, nos toca aliarnos a alguno. Esto en el ámbito de la ciudad. Si existiera un político de nuestra etnia, seria con la necesidad de formarse con nuestras propias ideologías ancestrales, que para nosotros consiste en inculcarles a los jóvenes que se empoderen como profesionales, fortaleciendo la misma comunidad. De esta forma, el día que lleguen a ocupar un espacio público, tendrá lugar la lucha por los derechos del pueblo.

Si nos hubiesen invitado, el análisis que se hubiese hecho ante el acuerdo sería una verdadera reflexión que buscara desaparecer el daño de los pueblos indígenas, no solamente de los Pijao, pues todos sufrimos el dolor y la miseria que nos ocasionaron las Farc. Es complicado un perdón, es muy difícil perdonar, como decía mi padre, es muy difícil perdonar cuando la sangre de tus hijos te ha bañado tus pies.

Entre las peticiones, está que el indígena desde la colonia fue desplazado de sus territorios, fue ubicado en territorios estériles que no 
producen para la manutención. El fenómeno de la restitución se logra sobre territorios fértiles, ya que los resguardos indígenas se encuentran en territorios estériles, lo que conduce a que siempre estén sometidos a la pobreza. El Estado debe ofrecer capacitación. Nuestra participación buscaría el reconocimiento de la guerrilla de la violación de los derechos humanos contra los pueblos indígenas, lo que ha sostenido la pobreza y la violencia, pero eso nunca se va a dar...

Históricamente, no ha existido un reconocimiento, ha habido luchas que han servido, está Quintín Lame en el siglo pasado, sin él, no se hubiera dado el reconocimiento que hoy día se ha dado. El reconocimiento ha quedado contemplado en políticas sin aplicarse.

Después de todo esto, puedo definir al indígena como aquellos que hemos asumido en la lucha que me he apropiado por el reconocimiento de los derechos por tantos años, pero que seguimos ignorados en muchos espacios donde debiera haber más participación.

En la actualidad puedo decir que mi sueño se ha hecho en una parte, ser un líder, tratar de ocupar espacios de liderazgo, no solo en la etnia sino también donde trabajo, en la empresa yo manejo el Comité de Convivencia, en el barrio he liderado la mejora de las vías públicas desde el año 2000, como es el caso de la luz pública, de las bancas públicas, son gestiones que con el apoyo del Distrito he logrado consolidar. Es que nosotros los colombianos creemos que todo lo debe hacer el Estado y no es así. No todo se debe dar, hay que luchar por conseguir

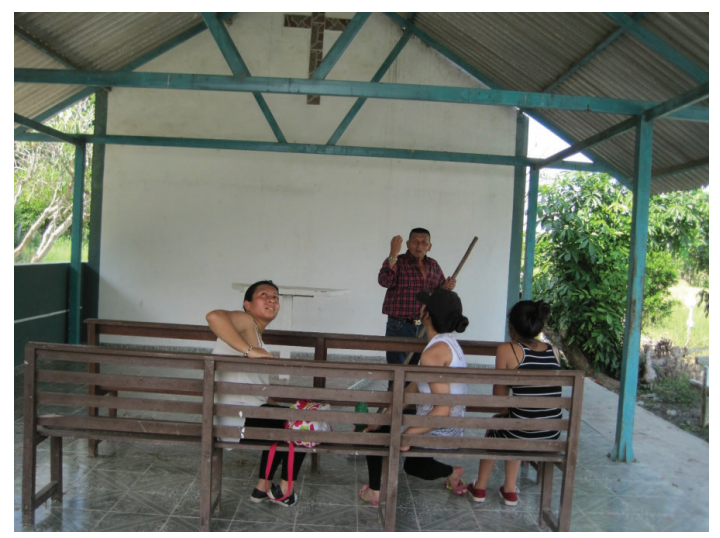

Marco Tulio Yate Yara 
las cosas suyas. Yo soy quien lo tengo que expresar, quien lo sufre es quien tiene que decirlo. A diario le inculco a mi comunidad que para superar las condiciones de vida, la mejor arma es el estudio, si es bachiller queda condenado a un salario mínimo, si es tecnólogo a 2 salarios mínimos, y eso ya es una mejor condición de vida. Yo les inculco a los niños desde pequeños debido a la ausencia que se vive en la ciudad. Hay familias que no se unen y es necesario unirse, se pierde el respeto, el fortalecimiento interno de la misma familia, existen momentos muy sagrados como es la comida. Es necesario reflexionar sobre lo que se hace y lo que no se hace. Si se hace lo contrario lo que se va a encontrar a futuro son padres solos.

En Bogotá, la mayoría de las familias indígenas se conservan. En mi caso personal, mi esposa no es indígena, a ella le gusta mucho mi cultura por lo que respeta el trabajo paralelo que hago al sostenimiento de mi núcleo familiar. Mi esposa se llama Graciela Machuca Pérez, con ella nos conocimos desde niños, cuando yo venía a Bogotá a donde mi hermana, pero con el tiempo se dieron relaciones de sentimientos que nos llevaron a unirnos a pesar de no estar casados. Tenemos tres hijos, Martha Cecilia, ella es licenciada en Pedagogía Infantil, Oscar Rubén, él trabaja en Salud Pública con el Distrito y Gloria Milena, que es profesora de Integración Social. Antes, tuve una esposa anterior, ella se llama Elvinia Castiblanco con quien tuve tres hijas, Vilma Marcela, Carolina y Diana Patricia, ellas tres son todas enfermeras. Yo he buscado el fortalecimiento de mi familia, a pesar de ser madres diferentes he estado pendiente de ellos. Mis hijos han trabajado también en la comunidad, a ellos no les afecta esto, aun cuando su madre no sea parte de la etnia miran con orgullo su herencia, su apellido.

Lo que yo cuento es alguna realidad de lo que se vive y se lucha, de lo que tenemos los indígenas y lo que se ha reconocido es muy poco para la deuda social que se tiene. Esta es mi historia de vida de la cual puedo rescatar que de las enseñanzas de mi padre en relación con el actual contexto de paz me ha quedado que "Una paz verdadera nunca se logra con firmar acuerdos cuando la sangre de tus hijos han bañado tus pies". 


\section{Historia de vida de Marcelina Cundumi Díaz, contada por ella misma}

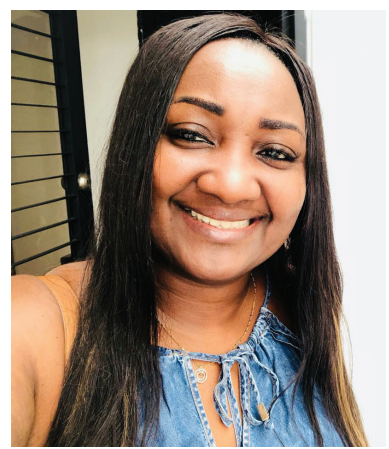

"De todo lo que viví me ha quedado la enseñanza de que somos una comunidad marginada, abandonada por el Estado, pero también somos un potencial guerrero e intelectual para construir este País que tanto lo necesita. Noto con gran tristeza que siempre los derechos que esta raza negra, palenquera, afrocolombiana, como se quiera llamar siempre han sido luchados, desde antes y hasta ahora, siempre han sido peleados".

MARCELINA CUNDUMI DÍAZ

$\mathrm{H}$

ay que tener en cuenta que nací en una comunidad muy vulnerable, de escasos recursos. Con un padre que gracias a Dios tuvo un poco de comodidad con muchos esfuerzos, fue un Caballero, un líder, un empresario y emprendedor. Luego, le cuento la historia de mi padre y de mi madre. El hecho que más me marcó para yo poder tomar estas luchas es que mi padre veía que los jóvenes se comprometían a muy temprana edad a formar familias quizás sin un futuro de unos estudios previos para mejorar el bienestar. La educación era muy mala, con muy pocas ayudas de parte del Estado. Pero un padre que no tuvo hermanos, hijo único. El único hermano que tuvo murió muy joven, fue mi tío José. Y mi padre solo quería vernos mejor, no formar familias sin futuro. Nací en el Corregimiento número 8, carretera Simón Bolívar, vía que conduce a Cali, vereda San Marcos. Él, cuando teníamos la edad de nueve años, nos sacaba a estudiar a Cali. Me marcó mucho 
el tener un padre que, a pesar de no tener estudio, era muy inteligente y siempre tenía presente que sus hijas no iban a quedar embarazadas formando un hogar sin primero estudiar, ni se iban a quedar sin un estudios porque él decía que les había tocado muy duro, que sus padres no le habían dado estudio, pero que él amaba a sus hijos. Su familia eran sus hijos y su esposa Liboria Díaz Sinisterra, mi madre y eso lo impulsaba a él que nosotros teníamos que ser la diferencia. Lo que más me marcó fue que mi padre nos decía que teníamos que ser honestos y ayudar al pueblo. Yo veía que cuando alguien fallecía, mi padre compraba el ataúd o cuando alguien estaba muy enfermo, mi padre lo llevaba a las mejores clínicas a la ciudad de Cali, y él pagaba los recursos. Él era muy humanitario, mi mamá también, entonces eso me impulsó a estas luchas porque él siempre decía: "Hijos-hijas, yo quiero que usted estudie Derecho para defender a la gente que no tiene quien la defensa. Hija yo quiero que estudie esa carrera, prométame que lo va a hacer para que defienda a la gente. Hija, yo quiero que usted estudie Derecho pero no quiero que estudie el Derecho penal, porque el Derecho Penal cuando no se trabaja a bien no da recursos para sostenerse, además traes muchos problemas, pero quiero que estudie un Derecho que sea humanitario, social para poder servir".

Me incliné por el Derecho Administrativo y luego por los Derechos Humanitarios, por ser líder comunitaria de acuerdo con los ejemplos que hacía mi padre, me incliné y le recuerdo más grande que tengo es cuando quedé becada en la Universidad Libre, pero a mí no me gustó la libre. Mi padre lloraba de la emoción. Yo me metí a la Universidad Santiago y él me decía, "yo quiero que seas abogada para que ayudes a tu misma gente". Eso fue lo que más me marcó. Yo siempre quise trabajar en el Derecho para ayudar a mi propia gente y aún lo hago, eso me marcó porque mi padre me decía tengo doce hijos y de los doce hijos como no va a haber alguien que sea abogado. Yo necesito un abogado en la familia. Eso me marcó.

Me marcó el hecho de que mis padres venían de pueblos lejanos, él llegó de Guapi. Él me contó su historia que él se había venido en una barquita porque los papás de él, mis abuelos: Marcelina Sánchez Mina y Eladio Cundumi Ocoro, ellos trabajan muy duro. Él me contó que ellos trabajan en una mina, mi abuela se colocaba una piedra 
para zambullirse al rio y poder sacar oro y poder sostener a él, que era el único hijo que le quedaba. Y mi abuelo cortaba, madera, trozas de madera. Entonces él al ver que sus padres eran muy pobres y no tenían cómo sostenerlo, decidió venirse desde muy niño hacia Buenaventura. Me marcó que él me decía que estuvo en las puertas de la empresa Puertos de Colombia, pero un día un gringo le nombró la madre y él se sintió humillado y, él le dijo a ese gringo que él no era esclavo. Mi padre me contó que había dejado ese trabajo y había decidido trabajar como independiente con Cartón de Colombia, en esa empresa despachaba madera y logró tener sus recursos, los cueles le permitieron costear gran parte de nuestros estudios.

Yo veía que mi padre solo sabía leer, pero era un hombre sumamente honesto que sacaba la madera que ellos halaban para vender a la empresa. Yo veía como mi padre solamente sabía leer pero era un hombre sumamente inteligente y mi madre una mujer ama de hogar, dedicada a nosotros.

A la edad de 9 a 10 años nos sacaba a Cali y nos ponía en los mejores colegios, nos colocó una empelada y nos decía que solo teníamos que estudiar, que responder por esa parte, que no teníamos que trabajar, que teníamos que ser diferentes, que teníamos que hacer lo correcto y siempre nos inculcó eso.

Mi padre falleció a la edad de 84 años de un infarto fulminante, mi madre aún vive de la edad de 81 años, ella se vino de la edad de ocho años de Timbiquí (Cauca) en un barco. Al igual que mi padre, ella se vino en busca de oportunidades, antes de conocer a mi padre lavaba ropa en casas de familia en la ciudad de Cali, lavaba ropa y planchaba. Desde muy niña, le tocó trabajar hasta que se conoció con mi padre. Ambos de origen caucano, mi padre le brindó un hogar y una estabilidad económica, le procreó 12 hijos. Mi madre no tuvo estudios, pero es una mujer muy sabia y muy inteligente, siempre nos cuidaba y nos decía que teníamos que proteger nuestra virginidad porque si no, no íbamos a terminar nuestras carreras; porque en esa parte, en esa cultura ancestral, ella decía que cuando el hombre tocaba a la mujer, ya no tenía validez la mujer que no estuviera en el matrimonio. Nos dejaban solos en Cali, y ella al principio bregaba a completarnos lo del semestre, pero cuando mi padre empezó a hacer dinero, ella se dedicó al hogar. 
Los padres de mi madre se llamaban Justa Sinisterra y Ambrosio Díaz, mi abuelo era un hombre muy reconocido en el pueblo de Timbiquí. Mi abuelo era una persona muy reconocida porque él tocaba el Clarinete, cuando alguien fallecía él tocaba el clarinete y hacía toda la ceremonia, él lo tocaba muy lindo. Él llegó a procrear más de veinte hijos de los cuales nació mi mamita; prácticamente se vino como a escondidas de ellos, porque se vino en busca de oportunidades.

De mi infancia puedo recordar para también ser líder, que el lugar donde yo nací es un lugar turístico. Yo nací en el suelo, con partera. Mi madre aún conserva su matriz, ya que allí, los partos eran caseros. Yo nací en esa vereda en el piso, a pesar de tener unos padres que tenían modos en el pueblo. Se podía decir que era la familia más esforzada, de acuerdo con el trabajo de mi padre por conseguir su patrimonio, dejó muchas tierras de las cuales hoy mi madre, que aún vive, aún las tiene y se las ayudamos a sostener.

A mí marcó eso que le digo, ver que la mayoría de los jóvenes formaban hogares a muy temprana edad, yo quería ser la diferencia, y también me marcó que la gente de nuestra comunidad en su mayoría casi no sabía leer ni escribir, ni tenían un título para esa época. Entonces mi padre nos inculcó mucho eso, que sus hijos tenían que estudiar, decía que sus hijos tenían que servirle a esa misma comunidad. Eso me marcó. Ese es el compromiso que yo tengo y yo amo esa comunidad por eso. Porque mi padre decía que sus hijos tenían que servirle a esa comunidad algún día, de hecho, todos lo hacemos. Yo tengo 11 hermanos los cuales están vivos, está Sonia (q. e. p. d), Myriam, Gerardo, María Teresa, Yolanda, William, José (q. e. p. d), Juan Vicente (q. e. p. d), Luz Emilia, Eladio, Diana María, Martha Cecilia, Ofelia (q. e. p. d), Lucely, Rosa y yo. Mi hermana Myriam es inspectora de cámaras de seguridad, estudio todo lo que tiene que ver con cámaras de seguridad portuaria, le sigue mi hermano Gerardo, luego Sonia, que era una mujer muy reconocida políticamente, era la directora de la sociedad de acueducto y alcantarillado de Buenaventura y falleció en un accidente, de la carretera que conduce a Cali-Buenaventura de 42 años; era una mujer muy reconocida, políticamente. Ella dejó una niña que se llama Sandra Lorena Quintero, a quien ella decidió entregar antes de fallecer a mí. Esa niña quedó huérfana de papá y mamá, estudió medicina 
y aún vive conmigo. Luego nació mi hermana María Teresa quien es licenciada en idioma inglés, francés y español. Luego nació mi hermana Yolanda quien es licenciada en primaria y es inspectora de policía en la zona rural en San Marcos, donde vivimos. Luego nació mi hermano William que estudió el bachillerato y una carrera intermedia, no tiene carrera universitaria. Luego nació mi hermano José, que también estudió su bachillerato, a quien asesinaron, era buzo profesional y fue asesinado por un hombre que trabajaba con él en una contienda confusa, murió mi hermano en la edad de 39 años. Luego estoy yo, que soy abogada, administrativista, egresada de la Universidad Santiago, egresada de la Universidad Libre, estoy terminando una Maestría en Derechos Humanos ante Altas Cortes Internacionales. Soy delegada nacional de Consulta previa, soy delegada étnica ante la JEP, delegada ante el Consejo Comunitario y litigo. Luego, sigue mi hermana Luz Emilia, que es contadora pública, y ocupa un cargo de Contadora en la Alcaldía Distrital de Buenaventura. Está mi hermano Eladio, que estudió salud ocupacional. Diana María, quien vivió en España por quince años, se pensionó allá, estudió Gerontología y cuidó ancianos durante quince años y ya está en Colombia. Mi hermana Martha Cecilia que es técnica del Sena, trabajó con la Policía y ya está pensionada también. Mi hermana Ofelia que era enfermera jefa de un hospital de Cali y ya falleció por una enfermedad general. Mi hermana dejó tres hijos, de los cuales está Lorena que es egresada de la Universidad del Valle en Estadística y Patricia que es contadora y es diseñadora egresada de la Universidad Javeriana, también Miguel Payán Cundumi que es corredor de seguros a nivel nacional. Lucely que estudio Sociología y actualmente trabaja en la personería de Buenaventura.

Bueno, estudie la primaria hasta el año cuarto en la escuelita Sofía Camargo de Lleras una escuela en malas condiciones, que era toda de madera, abandonada totalmente por el Estado. De allí, mi padre me saca a estudiar a Cali, a la escuela Rafael Zamorano, y luego paso al Instituto Universitario Tulio Enrique Tascón, el bachillerato, de donde luego me lleva a la Universidad. Recuerdo mucho también un líder muy reconocido, Néstor Córdoba, que luchaba también mucho por las comunidades. Recuerdo que mi mamá en su juventud era una mujer muy sociable, hacía las zarzuelas en la escuela. Recuerdo que tuve 
una niñez muy sana, cuando salía a vacaciones en la ciudad de Cali me iba a San Marcos y mi mamá tenía un balneario, que aún tiene, y yo le ayudaba cuando era adolescente en la edad de 14 o 15 años y le ayudaba a mi mamá a administrar en las vacaciones en ese lugar.

Mi abuela me llevaba a sacar oro, a sacar oro puro en las minas, en una mina que ellos tenían, en una vereda más arriba que se llama Aguas Claras donde el agua es cristalina, recuerdo esa paz y esa tranquilidad con que se vivía, a pesar del abandono total del Estado. Recuerdo mucho que la carretera es destapada, pero a pesar de eso se vivía una paz absoluta, a pesar de que cerca existían grupos armados y que se oían masacres, San Marcos nunca fue violentado, se hizo violencia en los corregimientos de Aguas Claras y Zabaletas, pero San Marcos siempre ha sido un pueblo muy sano, muy tranquilo. Recuerdo una vez, a los jóvenes les llegaron unos panfletos que decían Che Guevara. Mi padre y mi madre cuando llegaron esos panfletos reunieron a los muchachos a la salida de la escuela y les advirtieron sobre esos caminos, que no fueran a coger a esos caminos. Y por eso allí no hubo esas masacres. Entonces, ellos nunca se metieron con mi padre, ni con la comunidad de nosotros, recuerdo yo de niña, en la escuela. Mi padre decía que eso era lo del Estado y que eso era lo que había del Estado, una escuela totalmente abandonada, una carretera que hasta hoy está destapada con piedras y hasta hoy son unas vías en mal estado.

Todos los Jeeps, los carritos que nos llevaban allá a la zona, eran unos carritos unos "Carpati", de niña recuerdo mucho eso, recuerdo de niñez los juegos ancestrales de la niñez, el puente está caído, recuerdo con mucha gratitud una niñez muy sana. Cuando llegaban mis vacaciones, recuerdo que mi madre y mi padre nos echaban cuentos cuándo nos acostábamos, nos contaban el del tigre y el conejo; recuerdo que nos enseñaba a cazar y a pescar. Me iba de pesca con él, nos amanecíamos en una piedra grande pescando y cogíamos guacuco. El guacuco es un animalito que le dicen corroncho en otras zonas, y amanecíamos pescando, que a pesar del abandono del Estado era una vereda muy pacífica y aún lo es.

Recuerdo que jugaba futbol con las otras niñas cuando teníamos vacaciones, y también recuerdo que mi padre no nos dejaba estar con los niños hombres, nos cuidaba muchísimo, muchísimo, era muy 
celoso con nosotras las mujeres. Y si usted nota, éramos más mujeres y apenas cuatro hombres, de los cuales solo quedaron tres. En totalidad somos doce hermanos los que estamos todavía viviendo en este mundo, gracias a Dios.

Cuando yo paleaba con las niñas de la vereda por alguna cosa, mi madre me castigaba con una ramita que se llama chispero que solo crece a la orilla del río. Y mi madre me decía que me iba a castigar porque me tenía que corregir, mi padre nunca me pegó, recuerdo que nunca me pegó, no conocí la mano de mi padre. Era mi mejor amigo después de Dios. Hasta ahora, siendo yo mayor, siempre me acompañaba a todo lugar, éramos las hijas consentidas de él, y era mi amigo, a quien yo le contaba todo, esos tiempos no vuelven...

Cuando ellos tuvieron que salir desplazados por la violencia en el año 98, cuando hubo masacres por los paramilitares en la comunidad de Aguas Claras y Zabaletas. El camión pasó por San Marcos, pero gracias a Dios no hubo masacres para nadie, ahí estaba mi padre, mi madre y mi hermana que era inspectora vivía en la zona. Recuerdo con mucha tristeza porque ese territorio quedó solo. Allí son ocho corregimientos pero todo quedó abandonado y hasta hoy hay gente que no volvió. Ahora que soy una mujer adulta voy allá y llevo a mis hijas a nadar porque es un paisaje divino con aguas cristalinas, pero con una ausencia absoluta del Estado; los políticos van pero a recoger votos y nunca vuelven, es un sector olvidado, hay mucha ausencia del Estado.

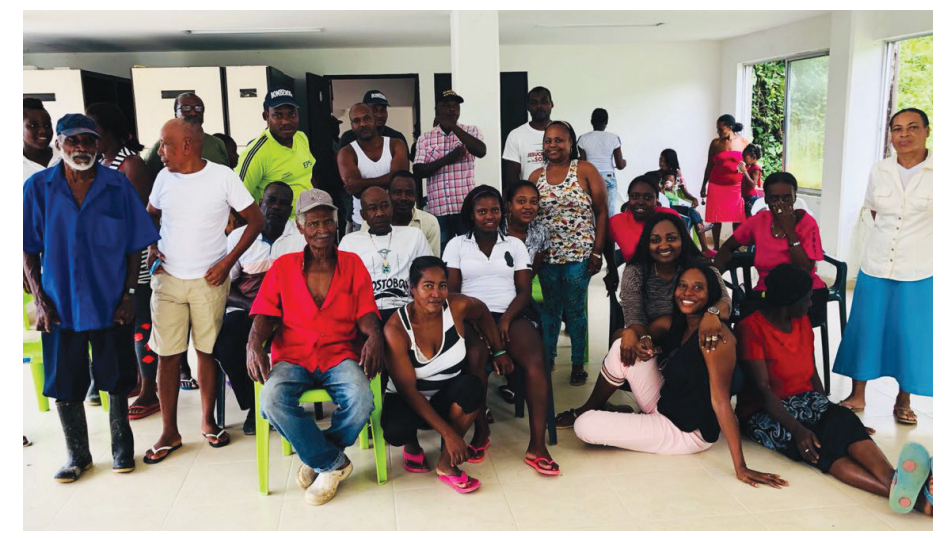

Marcelina Cundumi junto a su comunidad 
Siempre en mi familia hemos estado en la comunidad después de la muerte de mi padre, sobre todo mi hermana Yolanda y yo siendo defensora de los derechos humanos de esa comunidad. Siempre en diciembre llevo remesas, llevo regalos con lo que Dios me da, llevo muchas remesas y muchos regalos para los niños y las niñas. Hay mucha pobreza aún, hay mucha hambre aún, hay mucho desempleo aún, tengo una comunidad totalmente olvidada por el Estado. Tenemos las escuelas en mal estado, no hay canchas deportivas, las que hay son hechas por la comunidad, muy pequeñas, no hay espacios de recreación.

Sigo luchando por un parque allí, para esa comunidad que a pesar de que carece de todas esas cosas, tiene unos paisajes hermosos que lo hace todo muy atractivo y se respira un aire puro y una paz, una paz, es una comunidad muy tranquila, que los jóvenes a pesar del olvido del Estado no han cogido en su mayoría un mal camino.

Es turística, es una región turística, recuerdo de niña que los turistas, una vez, quisieron llevarnos como esclavos, que porque éramos niñas lindas y mi padre salió entonces con una escopeta y dio tiros al aire, y dijo que nosotras no éramos esclavas que por eso quería educar a su familia, que por eso no éramos esclavos. Recuerdo eso, me marcó mucho.

Los turistas de todas partes llegaban y aún llegan. Hoy ha cambiado ese contexto, hoy la gente está más abierta, yo le digo mucho a la gente a que eduque a sus hijos. Están metidos en diferentes programas de educación, lucho mucho para que la gente se prepare como yo, siempre en las reuniones les insisto en que la gente debe salir a buscar oportunidades y si no las encuentran deben volver a la región, porque la gente sale desplazada y sus hijos mueren por la violencia en barrios marginales, por ausencia del Estado. En barrios como el distrito de Agua Blanca en Cali, muchos de ellos se fueron buscando oportunidades y muchos de ellos no volvieron. Y porque los han matado o porque se quedaron trabajando en obras, de albañiles o las mujeres en casas de familia. Eso era lo que mi padre jamás quería para nosotros, y me siento orgullosa de mi padre, igual que de mi madre, hoy en día, ya la mayoría de las personas de la comunidad se esfuerza más para que por lo menos sus hijos estudien, pero no tienen ayuda del Estado con becas o programas educativos, acceder a ellos no es fácil para muchos. 
Recuerdo cómo sacábamos el oro cuando éramos niños. Cuando yo era niña, me gustaba ir a trabajar minas, me encantaba ir, aun cuando estudiaba me encantaba ir y cogía una barra que llaman a un instrumento y, picar la tierra y ver como salía el oro, trabajado de una manera ancestral, de una manera artesanal. Hoy en día, ya no se puede trabajar así, porque las grandes empresas decidieron meter maquinaria pesada, y ahora está el oro muy profundo. Pero yo de niña recuerdo mucho eso, con mi abuela Marcelina Sánchez, que me ponía en la frente un racimo de banano con una cargadera y yo lo cargaba.

También recuerdo que mi padre tuvo unos recursos económicos legalmente trabajando la tierra, despachando madera a Cartón de Colombia, trabajando la minería en los ríos a gran escala con dragas. Recuerdo que él siempre decía que teníamos que ayudarle a la comunidad, que teníamos que servirle a la comunidad, eso no se me olvida. Es como una tarea que tengo pendiente, y eso no se me olvida nunca, siempre lo llevo en mente, es como un compromiso, una tarea que tengo que terminar de cumplir hasta donde Dios me lo permita. Recuerdo que mi padre era un hombre muy envidiado, que le llegaban cartas por debajo de la casa que decía que desocupara el lugar, pues lógico porque era la persona que mejor estaba. Pero él les decía que no se iba porque él no le hacía daño a nadie. Nosotras nos escondíamos debajo de las camas cuando pequeñas porque era una violencia armada, quizá de la misma comunidad, de la vereda donde estábamos por envidia o de otras veredas, la verdad no lo sé. Pero ya con el tiempo eso fue pasando, eso fue cambiando cuando entendieron que lo que él quería era ayudar, pero siempre la envidia estuvo, no por todos, por algunos.

De todo lo que viví me ha quedado la enseñanza de que somos una comunidad marginada, abandonada por el Estado, pero también somos un potencial intelectual para construir este País que tanto lo necesita. Noto con gran tristeza que siempre los derechos que esta raza negra, palenquera, afrocolombiana, como se quiera llamar, siempre han sido luchados, desde antes y hasta ahora, siempre han sido peleados. Tengo tantas cosas para contar, como una demanda contra la empresa que se llama EPSA que cometió un lanzamiento de lodo hace muchos años dañando la flora, la fauna, la caza y la pesca de esa región. Y hasta 


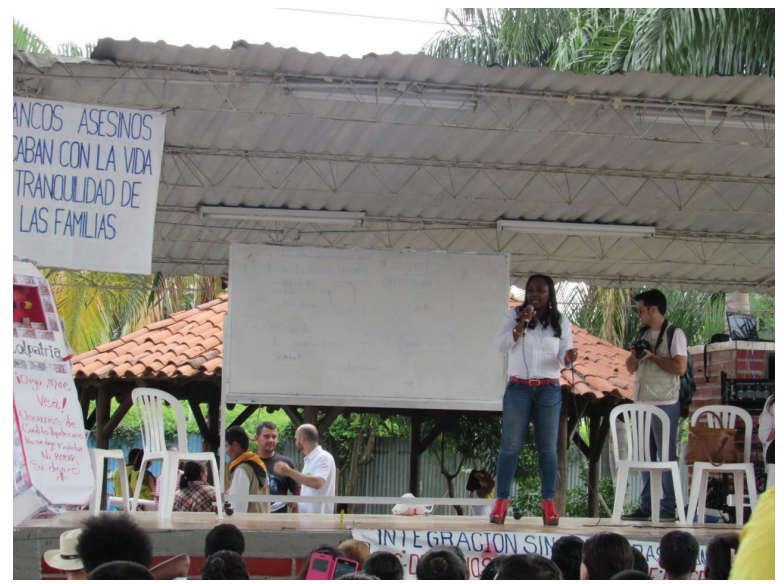

Marcelina Cundumi educando y participando en su comunidad

ahora, si el Estado ha fallado dos veces, es un expediente totalmente olvidado y no queriendo reconocer, habiendo sanciones contra la empresa y el grupo Unión Fenosa. Todo eso hace que uno tenga que tener un conocimiento superior para poder sacar a la gente del abandono de donde está, para poder sacar a la gente de donde está, para poder llegar a la esfera con el favor de Dios.

Son víctimas, podemos decir que somos víctimas, yo también soy víctima, a mí también me tocó salir desplazada por un tiempo, por esas razones, no poder entrar a la zona con mucho miedo, con mucho temor. Se interrumpió la tranquilidad, se interrumpió pues ya nadie quería volver allá, aunque gracias a Dios San Marcos no la vivió. Hay poesías que cuentan lo que pasó, hay un Poeta en la zona que se llama Wilson que hizo una poesía hermosa donde cuenta lo que pasó, él narra con lujo de detalles lo que pasó esa noche, el número de muertos, es una poesía cantada, es lindísima. Él es un poeta empírico. Y es muy triste, hasta ahora nadie ha sido reparado y tenemos personas de estas zonas que hasta ahora la Unidad de búsqueda las está entregando, y el Estado aun sin pronunciarse sobre el asunto, sin resarcir estos daños a estas personas y a esas familias.

En mi universidad, lo que más me marcaba era que en mi salón éramos 56 alumnos muy jóvenes, pero muy jóvenes y de esos apenas había dos personas que éramos afrodescendientes, lo que me marcaba, 
porque eso me hacía que tenía que esforzarme más, porque aún éramos minoría. Pero lo que me marcaba era mi desempeño académico, siempre iba adelante, siempre mis compañeros me respetaban, me hacía respetar en el salón.

Me marcaba que tenía marcado mi mundo y eso no me permitía entrar a los bares del mundo de la modernidad, porque mi madre siempre nos decía que teníamos que no dejarnos contaminar y mantenernos vírgenes al matrimonio, que mi padre lo iba a notar en el caminado, eso era algo ancestral. Ese fue un mecanismo de mi madre para que nosotros nos conserváramos para terminar la carrera, porque ella decía que si nosotras caíamos en eso no podríamos terminar la carrera, que ella no nos podía cuidar a toda hora, estábamos con una empleada, entonces entre nosotras nos cuidábamos.

Recuerdo que con los profesores les gustaba mirar mis manos porque mis manos siempre han sido muy rusticas, recuerdo que tenía un profesor que miraba mis manos y me las cogía y me decía que mis huellas eran muy marcadas que si era la comunidad de donde venía o porque me gustaba el trabajo rustico. Y yo le decía que era porque yo en mis vacaciones me encantaba ir con mi abuela a la mina de oro, que era como un hobby, irme a la mina con mis manos a maltratarlas recogiendo las piedritas de la mina.

A mi padre no le gustaba que hiciéramos trabajos forzados, recuerdo que teníamos ganado y cuando salía de la Universidad, me encantaba salir a arriar ese ganado. En la universidad siempre me destaqué porque me encantaba exponer, exponer las historias de mis comunidades y cantaba, cantaba las canciones de mi cultura y ganaba premios por cantar. Cantaba canciones como "Yo me llamo cumbia, yo soy la reina por donde voy". O sea, me encantaba siempre hacer la diferencia de mi cultura "No hay cadera que se esté quieta por donde estoy" siempre hacía la diferencia, como marcando la diferencia de donde yo venía pero a la altura, con un reconocimiento destacado. Siempre recalcaba eso, mis compañeros me querían y me recordaban por eso. Aún me hablo con algunos de mis compañeros, hasta con los del bachillerato.

Yo invitaba a mis compañeras de universidad a ese paisaje que es tan divino, del cual muchas personas se pierden. Hacíamos bodas en la playa, mi madre encantada atendiéndolos. De Cali a ese lugar hay 
perfectamente tres horas y media, no hay más. Hoy hay dos horas y media, cuando la carretera estaba más mala habían cuatro.

De mi padre, yo puedo recordar que decía frases como esta: "Mija cuando seas profesional recuerda que todo palo no se pica ni toda leche se toma". ¿Y qué significa eso? Que te van a proponer negocios que aunque se ven jugosos, tú no los puedes recibir. También decía que "nadie comía gallinas gordas con manos ajenas" que había que esforzarse, que no le gustaba ver a nadie que estuviera en el tejado parado, que la gente siempre estuviera activa. Era un hombre muy simpático, muy mujeriego, vago pero a la vez muy activo, no se dejaba ver ni se dejaba notar de mi mamá, pero cuando fuimos creciendo nos dimos cuenta que era como el chacho del pueblo. De pronto eso hacía que hubiera mucha rencilla, era un hombre muy atractivo, muy activo. Puede que en un momento de su vida fue muy vago, muy mujeriego, que puede que mi madre hubiera sufrido mucho en ese momento, todo fue tomando su norte a medida que nosotros íbamos creciendo.

Yo recuerdo que mi padre hacia parte de la Junta de Acción Comunal porque antes no existían los consejos comunitarios. Yo recuerdo de él que dejó mucho, dejó carreteras hechas con esa maquinaria pesada que él tenía. Hoy somos dueños de esas hectáreas, muchas hectáreas de bosque; tenemos un bosque que dejó mi padre, que no lo dejamos tocar ni de la CVC ni de nadie, es un bosque natural que tengo pensando conservar un parque de reserva natural, lo cuido muchísimo, hay extensiones de carretera que él construyó. De niña yo me pegaba a ese buldócer con mis hermanos, los que él construyó carreteras, hay quebradas cristalinas de aguas. Él era líder comunitario de la Junta de Acción Comunal, eso fue también lo que me llevó a ese liderazgo, él era presidente de esa Junta de Acción Comunal.

Mi hermana Yolanda en el liderazgo que hace con las personas, de las personas que están en extrema pobreza porque viven en casas de madera que están en el olvido del Estado. No hay proyectos del Estado. Ella ayuda a las personas de la tercera edad a que les paguen el auxilio que les da el gobierno, o cuando se mueren que les ayude el Estado o la Alcaldía con los cajones, o cuando están enfermos, cuando no tienen recursos, se busca la manera de llevarlos al médico si no tienen SISBEN, o cuando a alguien le están haciendo un tratamiento médico 
con enfermedad terminal, yo hago las tutelas gratuitas. Todo eso me gusta porque es la manera que encuentro de ayudar a la comunidad y de cumplir lo que decía mi padre. Yo recuerdo que él les decía "no tienen por qué odiarme porque mañana mis hijos los van a ayudar". También litigo en Derecho Penal cuando alguien lo necesita, en cosas muy pequeñas o muy puntuales. Y mi hermana también les ayuda a carnetizar y a sacar cédulas, las personas de mi comunidad en su mayoría son muy amables, pacíficas y trabajadoras, algo que me marcó después de terminar mi carrera dentro de las luchas que he hecho fue cuando cumplí 22 años, me fui para Bogotá y allí vivía mi hermano que siempre ha vivido, Gerardo Cundumi, quien me recibió. Me fui con la idea de trabajar, salir adelante, allí ayudé a hacer reclamaciones a la gente de Buenaventura y Cali que había sido mal liquidada de Foncolpuertos, comencé con la gente desplazada de Cali y Buenaventura. Nos fuimos con mi hermano a la Avenida Jiménez, a la calle 19 , calle 18 , que son puntos un poco peligrosos, comencé a meterme allá con mi hermano en charlas y después de mucho tiempo ellos me mandaron a buscar y comencé a luchar por las liquidaciones que les dieron cuando fue liquidada la empresa de Foncolpuertos, y ellos habían sido mal liquidados. Allí preste mis servicios como abogada haciendo conciliaciones administrativas, tuve la experiencia de participar en ello. Tuve reconocimiento de brazos caídos y todo eso. Viví por ahí 10 años en Bogotá y me devolví a Cali con la muerte de mi hermana Sonia, pues la niña que ella había dejado quedó huérfana, no tenía ni papá ni mamá. Quedé entonces radicada en Cali, litigando en Buenaventura hasta donde hoy lo hago.

En mis luchas he defendido a personas de raza negra e indígenas, a los hermanos de San Juan, del rio del San Juan, Chocó con sus reclamaciones como educadores, a los de Casur, policías, militares. Y en la actualidad, llevo una demanda de más de 8000 personas por todo el pacífico colombiano, defendiendo a esas comunidades. Es una demanda contra la aspersión, o sea por las fumigaciones del glifosato y han tenido prohibiciones por el departamento de salud y con pronunciamientos internacionales, y es una demanda muy linda porque allí estoy representando a todos los pueblos étnicos, tanto a indígenas como a tribales, que son la gente más pobre porque hoy en día 
no tienen un pancoger porque la tierra se quedó infértil. Hay muchas personas enfermas a raíz de eso, y es una demanda muy linda porque recojo todo su vivir, sus testimonios, fotos, también de los organismos estatales al hacer esas fumigaciones.

Yo diría que esta demanda tiene un contexto de cada cosa un poco, tiene que ver con el conflicto y con el postconflicto, estamos hablando de comunidades que en su mayoría no cultivan la coca y el Estado colombiano decidió bombardearlos de venenos fuertes desde el aire. Incluso la zona donde yo nací, el corregimiento número 8 y todos los lados para la Costa. Esa gente no cultiva coca. De pronto, los hermanos indígenas lo hicieron en un momento, pero las comunidades negras no son coqueros, no le jalan mucho a esa actividad porque son muy miedosos de eso. Los actores armados llevaron la coca detrás de ello, la implantaron, la impusieron y detrás de ellos, lógico que el Estado colombiano por conseguir su fin aparentemente con esa parte que también lleva violencia, incursiona contra esos territorios ancestrales de manera violenta, digo ancestrales porque con la Ley 70 para eso debían hacer enlaces con las alcaldías de esos municipios para poder entrar en esos territorios. La demanda es muy linda por la ausencia total del Estado, el Estado mismo las organiza, pero el Estado también tenía la responsabilidad de saber cómo las organizaba, tengo personas muy enfermas como consecuencia de eso, hombres totalmente sin erecciones,

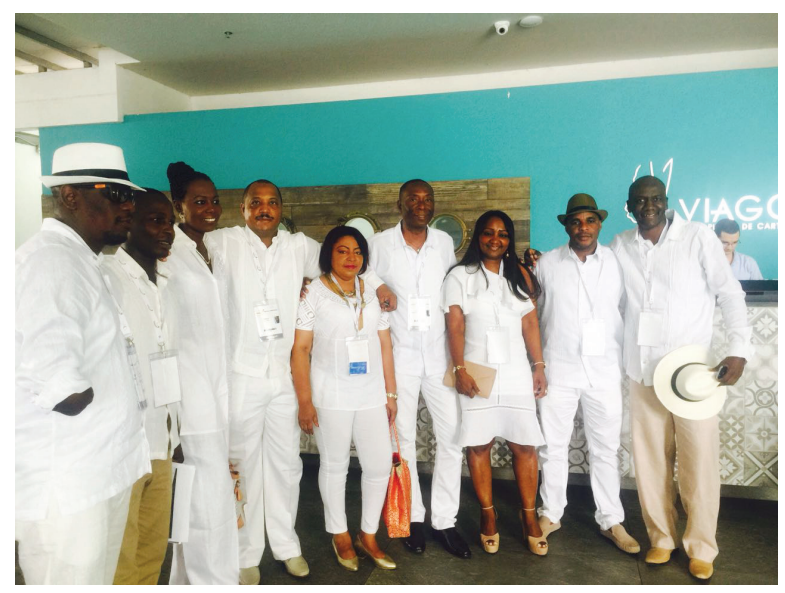

Marcelina Cundumi junto a otros líderes afrodescendientes 
mujeres con cáncer, consecuencia de esas aspersiones. Territorios ancestrales totalmente infértiles, incluso el mío, donde el potencial grande y la subsistencia primero Dios y luego era el Chontaduro. En el pacífico colombiano, del lado de Buenaventura, todo lo que es la Costa Pacífica ya no tenemos chontaduro, se trae un chontaduro caucano que es muy malo, pero el chontaduro bueno que era el sustento de la gente, la papa china, el pan coger, el plátano, el banano, el bananito. Todos esos productos que yo desde niña vi, que servían de sustento diario para todas nuestras comunidades, eso ya no lo hay. Tampoco hay proyectos productivos que permitan que esas comunidades avancen, al menos para sostener sus familias, no hay nada. Todos esos territorios que son territorios de paz, territorios ancestrales donde no reina sino la naturaleza, y hay un conjunto de cosas divinas, la paz interior, las almas de los ríos, una transparencia que se asemeja a la transparencia de la gente, que uno sabe que no tienen maldad, que viven en una pobreza porque son abandonados por el Estado.

Y si esto tiene de todo un poco, esta demanda es como la emoción, he invertido de lo que me gano con mi litigio en ella, lo que me gano lo invierto acá, porque son comunidades muy pobres que no tienen a veces ni para autenticar el poder, me toca costearles los pasajes a los hermanos indígenas que vienen del San Juan en lancha para poder traer sus aportes, porque son comunidades muy pobres, porque estoy en defensa de sus territorios ante el Estado y frente a su sustento diario, el Estado que les quitó todo y lo que buscó es que les devuelva del daño que les causó al dañarles las matas. Es una demanda que he estado consultado con el Ministerio con la UMATA, que cada mata tiene un precio y hoy esas matas no las hay, tenemos territorios totalmente áridos. Hoy se dice que es la minería y es algo que es falso. Son territorios que también tienen consecuencias de esa parte de la fumigación y si hablamos de la minería, la minería a gran escala la explotaron los paisas que en nada tiene que ver con el territorio, donde llegaban y saqueaban el oro, estilos españoles y se llevaban todo y las comunidades les pagaban un porcentaje y se quedaban sin el territorio y sin el material precioso.

Aún se vive ese flagelo, a pesar de los controles. Hoy, el Estado no nos deja trabajar, ni la minería, ni la pesca, ni la caza, pero tampoco da herramientas para subsistir. Hoy, el Estado tilda de delincuentes a los 
que trabajan la minería, o a los que trabajamos la minería porque a mí me encanta, pero ya no la podemos hacer de la manera como esclavos, como se hacía antes, metidos en un socavón; ya tenemos que hacerla a gran escala con la responsabilidad que eso implica, pero aun así se opone a que esos territorios puedan tener una mejor calidad de vida, argumentando que con ello llega la prostitución y la matanza, pero no es así, la prostitución llega donde hay ausencia absoluta del Estado, donde no hay un ejército o un a presencia de militares que puedan poner controlar o poner el orden en cualquier parte de este país.

Con todo esto puedo decir que hoy me he convertido en una mujer humildemente solidaria, con lo que puedo ayudar, ayudo gracias a Dios, quien me colocó en ese lugar, pero también gracias a la confianza de los miembros de mi comunidad porque hay un rol de grueso calibre que se debe asumir a la altura.

El proceso de elección comienza cuando yo he sido consejera comunitaria durante dos periodos, por lo que soy convocada por el Ministerio del Interior y de Justicia, por la Dirección de Asuntos Étnicos de Bogotá a ser parte de la elección de delegados Departamentales, de acuerdo con la sentencia de la Corte Constitucional T-576/14 que ordena la participación de los afrodescendientes, raizales y palenqueros, buscando la participación dentro de las medidas legislativas y, administrativas que afectan al pueblo negro. Con esta convocatoria logro pasar al primer filtro de elección, para luego dar paso a la segunda

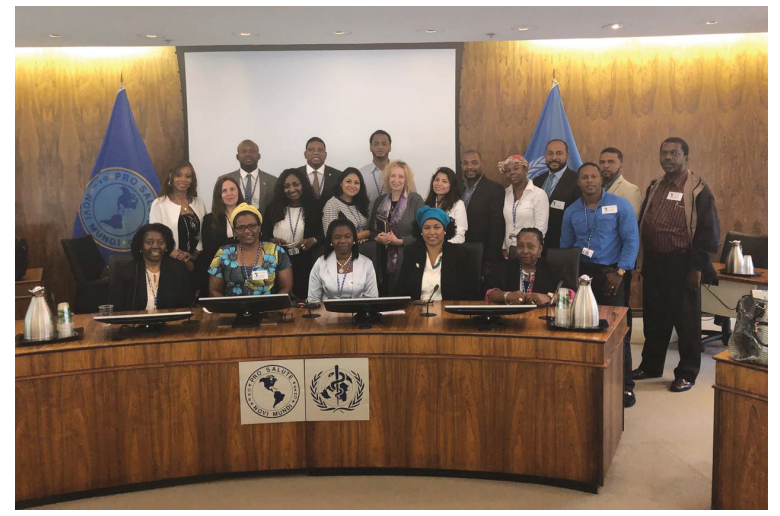

Marcelina Cundumi representado internacionalmente a las comunidades afrodescendientes de Colombia 


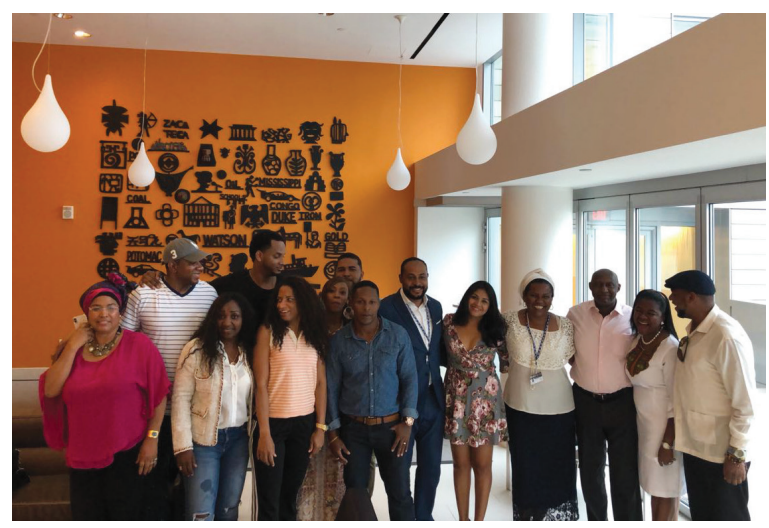

Marcelina Cundumi junto a otros líderes afrodescendientes

etapa que es la elección que se hizo en el Protocolo de Girardot, Melgar, la cual se desarrolló con la venia del Ministerio del Interior y protocolizada por el presidente de la Republica Juan Manuel Santos, siendo elegida por unanimidad de votación Delegada Nacional de Consulta Previa. En seguida se protocoliza esa figura frente al Protocolo de Quibdó. Posteriormente, en la ciudad de Santa Marta, en la Quinta de San Pedro, se hizo el ultimo filtro de elección, quedando fija en la lista de Delegada Nacional para las medidas legislativas y administrativas que afectan al pueblo afrodescendiente, raizal y palenquero. En otro proceso de elección quedé elegida en la Comisión Sexta en todo lo que tiene que ver con Justicia Ancestral, Derechos Humanos, paz y Postconflicto. Consecutivamente quedo elegida dentro de la mesa étnica que le hace un seguimiento étnico dentro de los acuerdos de paz dentro de la JEP. Un proceso que hasta hoy no tiene avances positivos para las víctimas ni para nadie. Por lo tanto, participo como Delegada Nacional de Consulta Previa, en la Comisión Sexta y como delegada de las comunidades negras ante la JEP.

Yo siento que a estas instancias he recorrido mucho, pero me falta mucho por recorrer. Siento que la voluntad o el sueño de mi padre luchando por las comunidades dentro del Derecho como especialista que soy dentro del Derecho Administrativo y ahora que me voy a graduar de la Maestría en Defensa de los Derechos Humanos ante Cortes Internacionales y Organismos Internacionales, pienso que ya he recorrido y me falta mucho por recorrer, con la venia de mi Dios. 


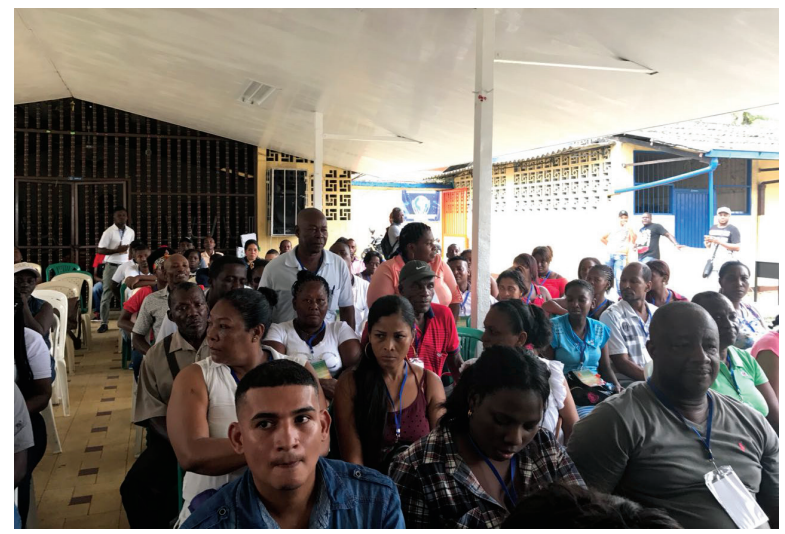

Reunión de la comunidad de Marcelina Cundumi

No digo que el sueño de mi padre se sienta satisfecho, porque yo digo que las personas que mueren ya duermen y no tienen participación en este mundo y están con Cristo Jesús y creo que mi padre está con Cristo Jesús, pero creo que su sueño en un momento dado de verme a mí como una mujer que lucha por ayudar a las personas que lo requieran en lo que a bien yo pueda. A mí, como Marcelina en ocasiones he tenido tentación de retirarme, pero cuando veo que hago un equipo donde tengo una conciencia, un interés, un conocimiento y sobre todo un corazón abierto a servir a esta sociedad, por nuestras minorías, como son los indígenas y el pueblo afrodescendiente, le pido mucho a Dios para que me permita continuar adelante, para que me permita luchar por nuestras comunidades de una manera limpia y sin el más mínimo interés personal. Pues solo deseo servir.

Creo que el trabajo lo hago bien, con errores como todo ser humano, pero que pongo corazón y conciencia y, sobre todo, amor en esta lucha, y el respeto a las entidades, reconociendo que somos minoría pero que eso no nos limita a que nuestros derechos sean reconocidos en un Estado colombiano donde hay una Constitución que nos ampara y un Estado que nos protege, pero que a la vez nos niega todos los derechos que nos da la Constitución y la Ley.

A nivel personal debo contar que estoy casada con Ladislao Liñán Martínez, persona oriunda de la ciudad de Cartagena, un hombre muy joven, con quien tenemos a Isabela y a Daniela Marcela, que tiene 17 años y está cursando el quinto semestre de Derecho en la universidad 
de la ISESI, e Isabela está cursando el cuarto año de bachillerato. Mis hijas son bautizadas en la Iglesia Cristiana, están siguiendo los pasos de Cristo Jesús, son unas niñas que nos han dado mucha felicidad por su formación, tanto académica, su disciplina y su comportamiento. A Daniela, le encanta lo que tiene que ver con las comunidades, son mestizas, son unas niñas que me han dado mucha felicidad porque recuerdo que casi que no pude tenerlas, las tuve a ambas por cesárea. En un momento pensé que mi Dios no me iba a permitir tenerlas porque tuve unas pérdidas antes de tenerlas, pero tenemos un hogar feliz. Tengo un esposo que también es un hombre muy noble, es administrador de empresas, está terminando ya prácticamente su carrera, tiene mucho conocimiento en la tecnología, es después de Dios, mi mano derecha, ya que a él le encanta todo lo que hago, es un hombre maravilloso, que nos da mucha seguridad en el hogar hacia mí y hacia mis hijas, quiero siempre seguir los caminos de Cristo Jesús, ya que sin él no somos nada, él es quien nos ampara y nos fortalece.

Ya para culminar quiero compartir dos poesías que dicen mucho, la una habla de la ancestralidad de la raza negra y la otra habla de la violencia que se vivió en el Corregimiento número ocho, que pueden ilustrar lo que he narrado. El autor es Wilson Caicedo, integrante del corregimiento número ocho, es agricultor y víctima del conflicto armado.

Poesía sobre la violencia que se vivió en el Corregimiento número ocho

El día 14 de junio del año 2003

Ese día me encontraba hablando con Don Andrés

Otro caso había pasado similar a éste

Mi corazón me avisaba que ya venía la muerte

Como a las 9 de la noche tres carros iban dentrando

Don Hugo los visageó y lo fueron degollando

Entraron a la variante y Hugo estaba acostado

Al lado de sus peladitos dentraron y lo han matando

El primer carro dentró y mucha gente no lo vieron

Y Pichenclao gritaba se metieron, se metieron

Tres hombres bajan del carro y empiezan a disparar

Cae Pichenclao muerto con dos tiros por detrás 
La Chacha se tiró al río y más allá se saltó

La muerte estaba en el puente y desde allá le disparó

La Caimana se encontraba escondida allá en la loma

Cuando oyó a Martha que grita me dieron en la corona

Nos bajamos de la loma asustados y preguntado

Entramos a la caseta y Moro estaba agonizando.

La casa de Rosaliano también iban a matar

Cuando oyeron los disparos se tiraron por detrás

La negra estaba escondida en la cama de Rosaliano

Salgase se allá señora que no le vamos a hacer daño

Se robaron el equipo, también robaron champaña

$\mathrm{Y}$ a toda velocidad se escondieron en el agua

Tomaron todas las noches pura bebida champaña.

Wilson Caicedo

Poesía sobre la ancestralidad de la raza negra

Hacia delante nos cogimos de las manos

Sembrando nuestros productos

Vino la fumigación y acabó con los frutos

Por esos estamos aquí parados y desanimados

Ya no queremos rosar, tampoco vamos a sembrar

Porque manda mi gobierno que nos vuelva a fumigar

A todos nuestros productos principales el chontaduro

Como es que hablamos de paz si no estamos bien seguros

No tenemos más que hacer vámonos a barequiar

si viene el helicótero también nos puede bombiar.

Quiero extenderme un poquito voy a hablar de enfermedad

Cuidado que con el tiempo también nos pueda matar

Porque el veneno es muy fuerte

A mí me quiso matar, me puso a tambalear,

también me puso a tumbar

Muchas palmas de chontaduro

Trajo muchos cucarrones y de eso estoy bien seguro

Que también comen maduro 
De un chivo que yo corté,

Lo azoté contra las palmas y a todos los machetié

Porqué eso es como matar gente

Eso es como la ruina o que decimos infierno

Pero toda la culpa se la echamos al gobierno

Vámonos a desplazar

Toda la comunidad vámonos a ir hasta allá

Estos son nuestros derechos

Quiero que usted mi gobierno ponga la mano en su pecho

$\mathrm{O}$ se pone a meditar y ve si tengo derechos.

Wilson Caicedo

“y esto yo lo dejo ahí, cójalo usted más allá componiendo lo errores y así lograremos la paz de resto es pura guerra”

Wilson Caicedo ${ }^{9}$

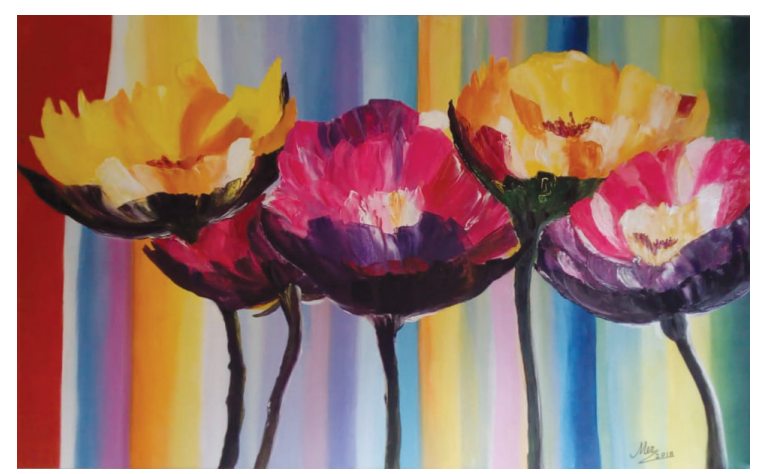

Pintura realizada por María Elena Rojas como un homenaje a la labor realizada por Marcelina Cundumi

MARCELINA CUNDUMI

9 Estas dos poesías fueron grabadas por Marcelina Cundumi con el fin de otorgar publicidad a la narrativa popular de Wilson Caicedo. 


\section{Historia de vida de Rosa Lilia Yaya Cuervo contada por ella misma}

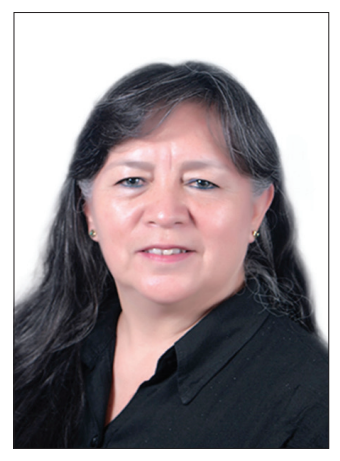

"Puntada a puntada, recuerdo a recuerdo, reconstruimos Memoria Histórica para la PAZ”.

ROSA LILIA YAYA CUERVO

i origen es Cajicá, soy la mayor de once hermanos. Mi papá y 1 mi mamá se casaron el 28 de diciembre de 1957, tuvieron siete hijos, los dos que me siguen murieron bebés. Mis padres eran de origen campesino, yo recuerdo a mi madre cuando yo tenía tres años y ella tenía en su barriga a mi hermano, quien nació el día que yo cumplí cuatro años. Mi papá era de Susa y mi mamá de Cajicá, mi papi fue desplazado junto con sus padres y hermanos por la violencia bipartidista, su familia era liberal, fue por esta razón que llegaron a Cajicá. Mi abuelo me contaba que él llegó caminando, tuvo que caminar mucho para llegar a Cajicá. Mis abuelos fueron cuidadores de fincas, mi padre se hizo entonces agricultor; mi madre era también mujer de campo. Cuando se casaron, ella se dedicó a la casa y a los hijos. Mi padre dejó la agricultura y se fue como contratista a montar e instalar las torres que daban energía a los pueblos cercanos a la capital, fue así que mis padres se trasladaron a Bogotá en busca de mejores posibilidades.

Vivimos en el barrio Samper Mendoza, donde nació mi hermano. Mi padre trabajó como mecánico y electricista en los Talleres Distritales que luego se convertirían en Obras Públicas, allí fue donde empezó la relación con la izquierda, con el Partido Comunista con el Sindicalismo, fue desde una formación autodidacta. 
Nacieron dos hermanos más, mi hermano y mi hermana, cuando mi padre estaba apasionado por la izquierda, la Unión Soviética, Cuba. Él estudiaba lo político, lo económico, lo social, estudiaba mucho, me le quito el sombrero en verdad de todo lo que estudiaba. Así fue como también aparecieron los inconvenientes, las desapariciones, la persecución, las torturas. Hizo parte entonces del Sindicato de Talleres Distritales, hoy Obras Públicas y de allí pasó por muchas más empresas donde hacía su trabajo político y sindical. Las empresas que más recuerdo son Panam, Cauchosol, luego estuvo en San Marcos, lo que le condujo a él y a la familia a tener mucho gusto por la pasta, él adoraba la pasta, era su plato preferido. Una de las últimas empresas donde recuerdo que él trabajó fue en Lafayette, también trabajo el tema de derechos sindicales, llegando a ser reconocido a nivel nacional como líder, lo que le empezó a imposibilitar su trabajo, motivo que lo condujo a trabajar exclusivamente desde el sindicalismo y la izquierda, siendo parte de la directiva del Partido Comunista y de la CSTC (Confederación Sindical de Trabajadores de Colombia). Esta situación nos dejó una carencia absoluta en lo económico ya que mi madre no trabajaba y nos tocaba de trasteo en trasteo.

Aunque teníamos muchas carencias que en ocasiones le ocasionaron a mi madre la necesidad de vender nuestras cosas para poder comprar algo de comida, o de dormir todos atravesados en una cama, a mi padre siempre le importó que estuviéramos en los mejores colegios. Mi padre nos decía que "lo que uno tiene en la cabeza y el corazón nadie se lo puede sacar". Esto se reflejaba en los diciembres donde en nuestros regalos más que juguetes nunca faltaban libros, enciclopedias, libros de literatura, etc.

La familia de mi mamá siempre la aconsejaba que se separara por justificaciones culturales y sociales que durante los años sesenta se escuchaban, le decían cosas como "la esposa de un comunista se iba a ir para los infiernos".

Mi mami después de la separación tuvo que irse de vuelta a Cajicá, trabajando en oficios varios, viviendo humillaciones. Yo le ayudé mucho cuidando a mis hermanos. Cuando llegamos a Cajicá, dada la situación económica, le aconsejaron que las hijas las metiera en una casa de huérfanas y abandonadas y a los hijos, también. Y a ella, le decían 
que se metiera de monja para salvar su alma por estar con un comunista. Ella dijo que de sus hijos no se separaría, ella siempre nos enseñó a estar unidos. El lazo de unión siempre estuvo presente, incluso con mi papá a pesar de que él no estuviera con nosotros físicamente, su presencia como autoridad siempre se hacía presente, porque ella siempre le preguntaba la opinión a mi padre de nuestras decisiones. En Cajicá nace mi hermana menor del núcleo de mi papi y mi mami.

En los años setenta, mi padre se fortaleció en el trabajo que hacía como dirigente político y sindical. En los Llanos Orientales, se veía la necesidad de la formación de cuadros, esto lo llevó a viajar frecuentemente a este territorio hasta que terminó radicándose en Villavicencio. Allí fue gestor de los primeros sindicatos agrarios y de salud, recuerdo ANALFERAUX y luego ANTHOC. Era el mediador de las conciliaciones laborales en estas empresas. Desde niña, él me llevaba, me acuerdo de negociaciones donde estaba María Elena de Crovo y alguna con María Teresa Forero de Saade quien estuvo luego en el discurso de su funeral.

Mi padre también trabajó lo de vivienda popular, buscando procesos de autoconstrucción, algo así como lo que se hizo en Bogotá con el barrio Policarpa. Ya en Villavicencio lo visitábamos en los puentes. En vacaciones, nos llevó en alguna oportunidad a un lote de autoconstrucción, que tenía como sorpresa para que nos fuéramos todos, pero mi mamá no quiso irse para allá.

Mi padre era un Don Juan, era atractivo, escribía muy bien, hablaba y se vestía muy bien, por lo que era muy apetecido por las mujeres. Él tuvo tres hogares, una esposa y dos compañeras. Una de las

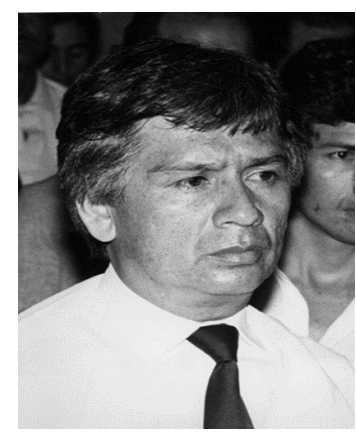

Luis Eduardo Yaya, padre de Lilia Yaya 


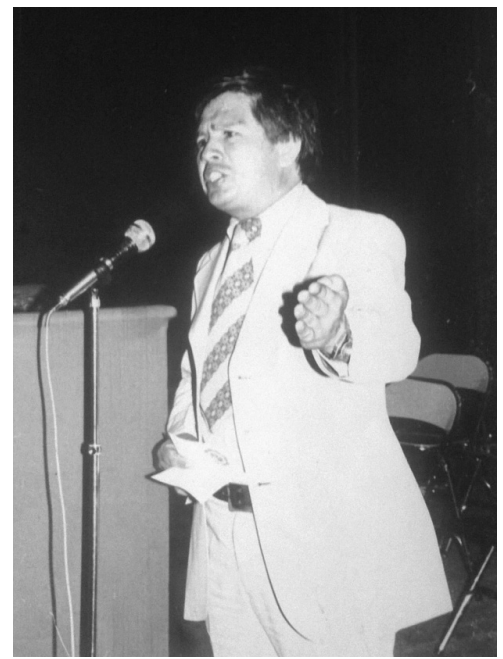

Luis Eduardo Yaya, padre de Lilia Yaya

compañeras era una fuerte dirigente, con la que tuvo tres hijas, una de ellas ya falleció. Con la otra compañera tuvo dos hijas y un hijo. Estas dos mujeres sí se fueron a Villavo junto a él, mi madre no, nosotros permanecimos en Cajicá. Yo los considero mis hermanos porque venimos de un mismo tronco, los he buscado, he tenido una buena relación con ellos, al fin y al cabo somos hermanos; todos admiramos, queremos, recordamos a mi padre, sin interferir a las madres, para evitar inconvenientes, nos une nuestro padre.

En Talleres Distritales, hoy Obras Públicas, él tuvo una formación sindical que encontré y recordé en el 2006 cuando entré allí a trabajar con un proyecto de gestión documental, donde recordé a mi padre, recordé que allí se había formado, por lo que busqué en los archivos a mi padre y lo encontré. Incluso encontré un permiso que pidió una tarde, se lo mostré a mi madre, y ella me dijo que debió ser que se fue con alguna mujer. Poco a poco allí me empezaron a reconocer, fue ahí donde inició formalmente mi trabajo de Memoria.

En la época en que mi padre estaba en el sindicalismo, le daban becas a los hijos de los trabajadores para que fueran a estudiar a la Unión Soviética, pero mi padre no me dejaba ir, en eso tenía un sentido conservador, el dejaba ir a los hijos hombres. A las mujeres no, porque decía que llegaban embarazadas y él no quería eso para mí. 
Finalmente, un día me dijo "Ya llegó la beca para Rumania", pero no la acepté porque le descubrí un romance y no quería irme. Entonces él me dijo que ¿qué iba a hacer si iba a la Universidad o al Sena? Yo no quería el Sena porque siempre pensé que allí formaban máquinas, por lo que me buscó un trabajo asegurado totalmente en LEC-LEE donde entraría a trabajar, pero pasaron los días y no me llamaban, así que decidí ir allí y vi mi carpeta con mi hoja de vida con dos rayas cruzadas: hija de sindicalista. Le pregunté a mi padre y él me repreguntó que había puesto en mi hoja de vida y le conté que en el formato Minerva de esa época puse la ocupación de mi padre como sindicalista.

Mi padre me dijo que nunca dijera eso, que dijera que él trabajaba en un criadero de gallinas. Yo no quería eso porque me sentía orgullosa de mi padre pero esa es una estigmatización que me ha costado toda la vida. Finalmente, estudié secretariado en el Sena y en la noche Derecho, por razones económicas solo llegué al quinto semestre.

En Villavicencio, asesinaron a mi papi, allí acudieron al funeral sus dos mujeres que vivían en esta ciudad. Viajamos a Villavo los cuatro hijos mayores; mi hermana menor, mi mami y mi cuñada que estaba embarazada, esperaban que regresáramos con su cadáver para sepultarlo en Cajicá. Esto era lo que pretendíamos, pero tuvimos que salir de Villavicencio por amenazas de muerte sin poder asistir a sus exequias. El asesinato de mi padre estaba anunciado, durante muchos años, la radio transmitía a diario los asesinatos que en la década de los ochenta sufrieron los integrantes de la UP, por lo que los sacaban constantemente

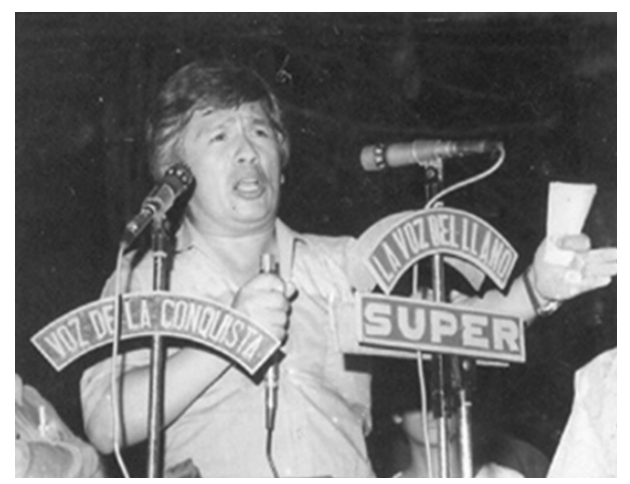

Luis Eduardo Yaya, padre de Lilia Yaya 
del país. A él le propusieron que se fuera del país a Checoslovaquia o a Alemania donde sería corresponsal, pero él decía: "No me voy, yo soy hijo del pueblo, no me voy". A mi padre, una vez, lo quisieron envenenar, sufrió muchos atentados hasta que el 23 de febrero de 1989 fue asesinado. La gente lo quería y lo aclamaba, por lo que lo acompañaron en la Funeraria muchísima gente. Fue después por el periódico que supe que a su funeral acudió María Teresa Forero de Saade con quien lo había visto en negociaciones colectivas durante su actividad sindical.

El último día que hablé con mi padre fue el 21 de febrero de 1989, un martes, dos días antes de su muerte. En esa época, yo trabajaba en la inspección de policía de Cajicá y en la familia nos encontrábamos pendientes de una beca para una hermana que quería estudiar Odontología. Mi papi decía que era muy costosa esa carrera y que él no podría pagarla. Meses antes había regresado un hermano de la Unión Soviética de estudiar medicina, lo que hacía difícil que mi padre buscara una beca para mi hermana, pues él decía que otros compañeros también lo necesitaban y que esa ayuda era para todos. Pero ese 21 de febrero de 1989 mi padre llamó y me dijo: "Ponga cuidado, le conseguí media beca a su hermana, así que vaya alistando los papeles de la gata. Yo tengo que ir ya sabe cuándo a contarles algo". En esa época por las persecuciones sabíamos que las llamadas eran rápidas y puntuales, por lo que en su llamada entendí que "ya sabe cuando" se refería a los cumpleaños míos y de mi hermano, con quien cumplimos años el mismo día el 25 de febrero, entendí que mi papi vendría a nuestros cumpleaños y lo que nos "tenía que contar" creemos que nos iba a decir que estaba alistando las maletas para irse del país, ya que días antes lo había acompañado a comprar varios vestidos.

Ese fue el regalo del Estado que no olvidaré... Mi papi fue muy especial conmigo, me mandaba flores, me dedicaba libros. Cuando cumplí 17 años me regaló rosas rojas y decía en la tarjeta: "Para mi adorada hijita en sus 17 primaveras. En cada flor van mil caricias para esa flor que hace parte de mi jardín” Tu papi.

Yo siempre he admirado a mi papá. Yo creo que ni yo, ni mis hermanos le llegamos a los tobillos, jamás, porque siendo tan humilde con tantas carencias formó a mucha gente. Muchos recuerdan a Pizarro y a Jaramillo, pero a los maestros humildes del pueblo no los recuerdan. 


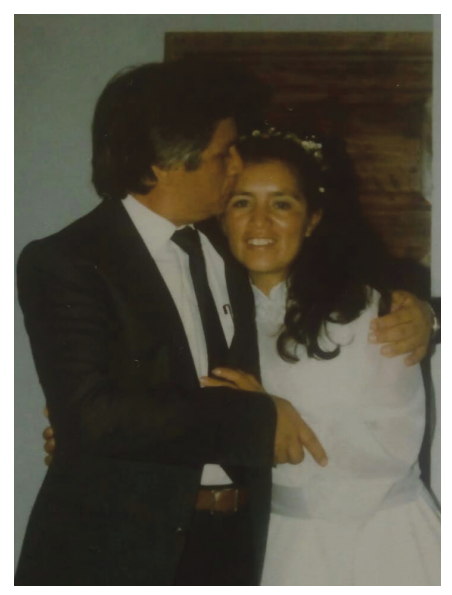

Lilia Yaya junto a su padre.

Sin embargo, esa labor nos costó bastante a mi familia, los zapatos rotos remendados, la ropa regalada que teníamos que usar, me daba rabia con la vida, la falta de alimento. Me acuerdo de una anécdota que mis hermanos recuerdan con risa pero yo no. Nosotros vivíamos en una pieza encima de una panadería, teníamos mucha hambre y nos llegaba todo el olor del pan. El cinturón de mí hermano tenía una moneda de 10 centavos pegada. Yo tenía casi 8 años, él casi cuatro, los otros eran muy pequeños; despegamos la moneda y pudimos comprar el pan, lo celebrábamos con alegría. Hoy, 52 años después, es un recuerdo que no me da alegría. Esto era problema de los más humildes, mis hermanos decían que vivíamos con una claraboya natural, porque podíamos ver la luna y el sol, lo decían en chiste, pero a mí no me gustaba. A pesar de estos malos recuerdos, respetamos y admiramos mucho la labor de mi papá.

Este último cumpleaños cumplí 60 años. Uno de mis hermanos no pudo asistir, pero nos envió una grabación de mi papá, la escuchamos y ratifico que los hijos lo admirábamos pero los nietos lo critican, porque ellos se preguntan que cómo podíamos admirarlo con todas las necesidades que nos hizo pasar y el desorden de vida sentimental que llevaba. Pero nosotros los hijos lo admiramos por los valores de vida, por la herencia que nos dejó la obra de mi padre, su vida entera, él siempre decía que: "Uno tiene que entregarse a la comunidad"; "siempre recordar de dónde viene, mirar atrás y jamás negar sus orígenes”, 
recordar que salimos del barro de todas las necesidades que pudimos tener, de nuestros zapatos desfondados pero ahora teníamos que vivir bien; también decía que "a uno no tiene que darle miedo entrar a una tienda o restaurante elegante, uno también tiene derecho a vivir bien y disfrutar de la vida".

Yo siento respeto y miedo a defraudar esa confianza que nos brindó. Él decía que "la educación es una forma de libertad", que "se puede andar entre lobos y no aprender a aullar", "que uno tiene la decisión y la voluntad para elegir, todo enmarcado en el respeto", "mirar siempre a los ojos, a nadie se le baja la mirada porque todos somos iguales". A mis hijos les inculco esto, les digo que no siempre papá y mamá tienen la razón, que deben respetar, sí, las jerarquías, pero que en medio de las diferencias somos seres humanos iguales y merecemos igual respeto.

Aprendí de mi padre el valor del respeto y de muchas otras frases y palabras que siempre escuchaba en sus discursos, en lo que nos hablaba, aprendí el significado de este valor de la fraternidad, la solidaridad y la paz, de lo que realmente significan. Tengo una camiseta de PAZ que siempre llevé durante el proceso y hasta la firma del proceso de PAZ.

Durante mi adolescencia, mi padre me decía que entrara a la Junta de Acción Comunal, que trabajara con jóvenes que él me enseñaría cómo. Él me llevaba a las embajadas de Checoslovaquia, Alemania, Cuba, al Teatro Popular de Bogotá, a ver las obras que realizaban Patricia Ariza y Vicky Hernández, que eran consecuentes con esa mirada del Socialismo. Él tomaba mucho material del teatro, de las revistas de estas embajadas, donde encontraba propagandas y cuentos para sus charlas.

Una anécdota que nos ocurrió con mi padre fue con una película de muñequitos que quisimos poner en el pueblo, pero el único que tenía un aparato para reproducir la película era el párroco de Cajicá, cuando pusimos la cinta, quedó mal puesta, por lo que al darse cuenta que fallaba y que se presentaban muñecos soviéticos, no nos prestaron más el proyector.

Cuando éramos niños y jóvenes mi padre nos llevaba muchos libros, lo que hizo que yo leyera mucho y me acercara a estudiantes de áreas sociales, donde universitarias de estas áreas tenían un grupo de teatro en el que participé, pues sentía pasión por el teatro. Allí escribimos 

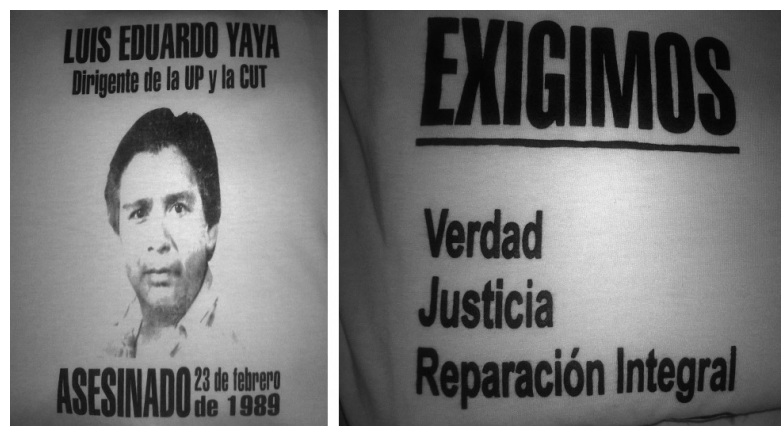

Camiseta con la que su familia sale a marchar pidiendo: verdad, justicia y reparación integral ante la impunidad

una obra que se llamó "La clase obrera". En el libreto hablábamos de la clase obrera, de lo que estaba sucediendo en el país y en el mundo. Me gustaba la música de protesta, me gustaba la canción "Una flor para mascar" de Pablo Gallinazus. Me gustaba mucho el libro "20 mil leguas de viaje submarino de Julio Verne”, mi padre me lo regaló y escribió: "Son para tu padre más de 20 mil los sufrimientos por no poder darte el calor que mereces, pero el día tiene que llegar en que siempre me tendrás a tu lado. Para mi adorada hijita Lilia”. El día de la muerte de mi padre, cuando llegamos a la funeraria, me acuerdo que las personas se abrieron para que entráramos, pero no me dejaron entrar; quien entró fue mi hermano médico a verificar que fuera él y lo peinó, y siempre guardó esa peinilla durante muchos años.

Cuando tenía entre 13 y 14 años desarrollé liderazgo en la Junta de Acción Comunal y años después en organizaciones de padres de familia. A mí me gustó todo lo que era la parte comunitaria, llevó 35 años de liderazgo que me condujeron durante mi edad adulta a decidirme por estudiar Sociología. En la vida laboral, fui reconocida como líder en salud ocupacional, fui Consejera de Cultura, candidata al Concejo de mi municipio, a la Asamblea. Yo no soy política porque yo no hablo carreta, me reconozco más como social y comunitaria. El $90 \%$ de mi vida laboral he sido servidora del Estado en entidades del orden municipal, distrital, departamental, nacional y ONG internacional.

Trabajé en un proyecto de gestión documental en la Secretaría Distrital de Obras Públicas, luego en la Secretaria de Gobierno de la Alcaldía Mayor, fue un convenio que había con la Pastoral Social 
y la Unión Europea, requerían a tres personas, entrevistaron a muchas personas, no encontraban a nadie con el perfil para trabajar con víctimas con ocasión de la Ley de Justicia y Paz, por lo que quienes me conocían me recomendaron porque me reconocían como líder comunal y social cumpliendo así los requisitos que requerían. Trabajé entonces con población desplazada, me toco con los habitantes del barrio 20 de julio de Bogotá, me tocó esta parte donde había personas desplazadas pero que escondían su identidad porque las veían como delincuentes, uno encontraba que ponían en las casas, en los apartamentos, en las habitaciones que arrendaban letreros que decían "No se arriendan a desplazados".

En este trabajo caí en cuenta de que yo nunca recibí atención psicoterapéutica por la muerte de mi padre, que después de su muerte yo duré tres días sin llorar lo que hizo se me despertara la agresividad por la tristeza en la que me encontraba. Yo no lloré porque yo era fuerte, nunca lloraba frente a mis hermanos ya que a los 10 años yo era quien los cuidaba cuando vivíamos en el campo, ya que allí ocurrían cosas graves, entonces me hice fuerte y siempre cuidé de mis hermanos para que nunca los tocaran. En nuestra infancia nunca nos golpearon físicamente.

El trabajo con víctimas fue un choque horrible, perdí la voz, recibí amenazas por mi pasado y la identidad de mi padre. Con las víctimas de Suba yo misma me hice las terapias por el impacto tan grande, esto me llevó a reunirme y encontrarme con más víctimas de la UP con

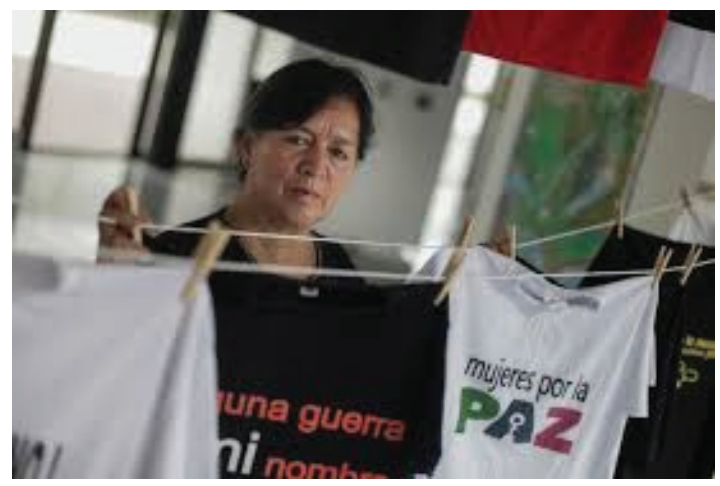

Lilia Yaya como mujer constructora de paz 


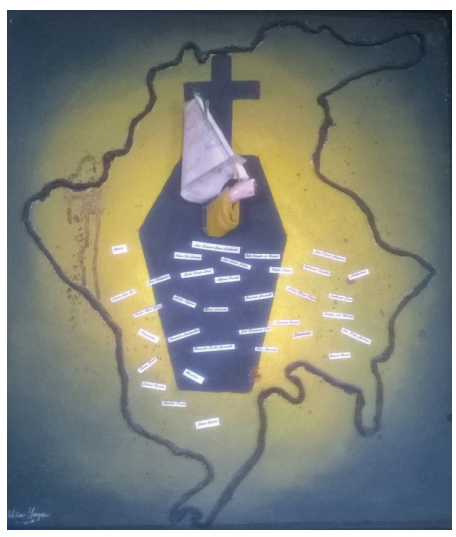

En este cuadro se observa un féretro al fondo con una cruz, está elaborado sobre yute. El yute representa la ancestralidad de nuestro pueblo colombiano. Tiene una mano sosteniendo una bandera blanca en la que se lee: educación, salud, justicia, fraternidad, libertad, igualdad, vida digna, cultura, democracia, PAZ; todas las consignas por las cuales luchaban nuestros militantes de izquierda asesinados. Los cuadritos pequeños tienen el nombre de personas allegadas que fueron asesinadas; el del centro es el de mi padre. Las machas que hay en el cuadro son de sangre. El cuadro fue elaborado por Lilia Yaya en 1993

la Fundación Reiniciar y con la Fundación Manuel Cepeda Vargas. Con esta última recibí una invitación para crear un Costurero de la memoria de víctimas de distintos casos. Fue difícil porque a mí no me gustaban las costura pero el sentido de este costurero era diferente, me llamaba la atención, allí todas me conocieron como una más de ellas. Allí hay madres de falsos positivos, hay mujeres desplazadas por megaproyectos (estas formaron otro costurero), familiares de los desaparecidos del Palacio de Justicia, donde en general son casos de violencia que les tocó a sus hogares.

Cuando pensé qué hacer en mis telas recordé que siempre me gustaron los mapas de Colombia porque estos representan la estructura política y social del país, ya que esta ha sido mi vida, toda mi vida desde que me conozco y desde antes de nacer. Es por eso que hago costura con mapas.

En el Costurero, hacemos la construcción de la memoria política y social del país en el marco del conflicto armado, buscamos el reconocimiento y la defensa de los Derechos Humanos, nos unió el dolor y los sueños del país, es la memoria lo que nos interesa. La primera tela que hicimos fue contando nuestra historia, fue difícil porque yo 
puedo bordar pero pegar un muñeco es muy difícil para mí. Sin embargo, imprimí una lista de las víctimas del año 89 y la pegué, de esta forma voy contando toda la historia de mi padre junto a lo que ha sido la historia de nuestro país.

Este es un homenaje a las víctimas de la década de los 80; hechos que asombrosamente, aún permanecen impunes; a los desaparecidos, torturados, exiliados, desplazados ... un Homenaje a sus familias... “1989, el año negro que está en la impunidad”. 1989... Este es un homenaje a mi padre Luis Eduardo Yaya Cristancho, asesinado el 23 de febrero. Un homenaje a sus Compañeros de lucha, utopías, de ideales. Un homenaje a los militantes, directivos, simpatizantes de la Unión Patriótica y del Partido Comunista. Un Homenaje a los campesinos, líderes sociales, defensores de DD. HH. y miles de colombianos asesinados hace 25 años en medio de la guerra de intereses políticos. Un homenaje a los MILLONES de Víctimas en Colombia». Lilia Yaya

Las tres hojas que se ven en la parte inferior derecha, es el listado mes a mes de las 106 víctimas de la Unión Patriótica en el año 1989.

Alguna vez, me preguntaba por qué mataban a tantas personas, por qué existía la guerra, por qué mataban a muchos inocentes, pero recordaba que mi padre me decía que esto era un tránsito a la paz. Es por esto que mi sueño es la implementación de los acuerdos porque con esto no solo consigo un beneficio para mi familia sino para mi país. Creo que mi padre esperaría que yo fuera como soy, que sus

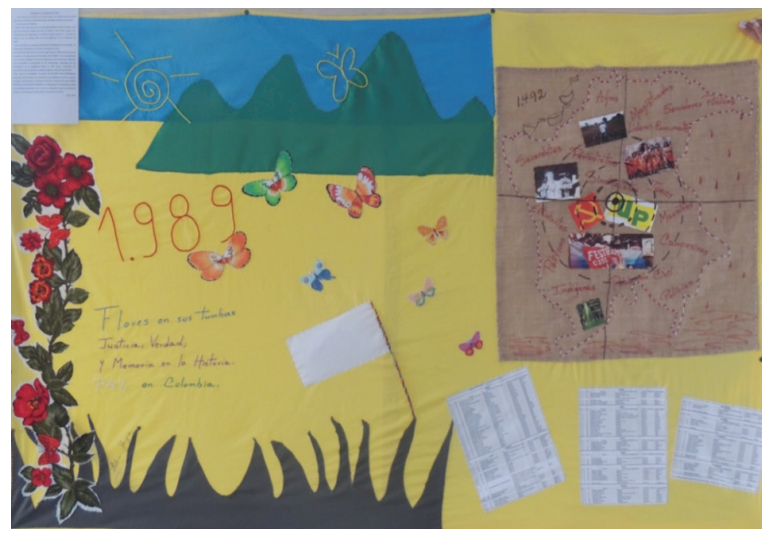

Homenaje a los mártires de 1989. Tela elaborada en el 2014 por Lilia Yaya 
expectativas sobre mí se están haciendo realidad pero comprendiendo que jamás le llegaremos al tobillo porque no tengo toda la verraquera que él tuvo, pero tampoco quiero que mis hijos y sobrinos se metan en esto por la estigmatización que he vivido y que no quiero que ellos sufran.

Mis sueños y mis expectativas es poder participar en los procesos de implementación de los acuerdos de paz, hay que hacer cosas a nivel nacional e internacional, me gustaría personalmente poder hacer una especialización en un país que haya vivido lo que es el conflicto, lo que es la guerra. Nuestra tarea es enumerar todos los casos. Podemos decir que trabajamos juntos por la paz, por la reconciliación porque no haya más sangre, pero no voy a perdonar. En el conflicto se han metido las clases menos favorecidas, nosotros, como víctimas, buscamos la reconciliación desde nuestra conciencia política en la que buscamos que se conozca la realidad de quienes, para qué y cuál fue el producto de la guerra para a partir de esto buscar qué vamos a hacer, pero para ello nos falta acceso a la justicia.

Como mujer siento que nosotras no debíamos haber permitido que ocurriera todo lo que ocurrió ni que siga ocurriendo lo que sucede debido al accionar de los dirigentes que entregan las riquezas de mi país a contratistas extranjeros. En materia de paz, a veces quisiera botar la toalla, yo digo que sufro un existencialismo personal, político, filosófico y religioso, incluso a veces digo que sería mejor ser ermitaño. A veces reniego de la vida, digo que para qué traer más hijos al mundo si esto está patas arriba. Pero a pesar de ese existencialismo, de la estigmatización, de las carencias, siento que existe la posibilidad de que uno siga soñando en un país en paz.

Quisiera poder participar en la JEP pero no he tenido el llamado ni la posibilidad de participar allí. Pero en diciembre del año pasado, con Reiniciar, tuvimos la oportunidad de realizar un simulacro de Comisión de la Verdad donde pude sentir que si esto sigue así yo me voy a morir esperando que haya justicia para los casos de la UP, esperando que se dignifiquen todos los que murieron por eso. Es por eso que estoy agarrada de una tabla que se llama acuerdos de paz.

En mi historia de vida puedo destacar que mi obra de teatro favorita fue la que hice en diciembre que se llama Tríptico Femenino donde 
aparece mi vida; de película la Estrategia del caracol: "Ahí está su puta casa pintada", y de mis tejidos puedo afirmar que: "Puntada a puntada, recuerdo a recuerdo, reconstruimos Memoria Histórica para la PAZ".

ROSA LILIA YAYA CUERVO

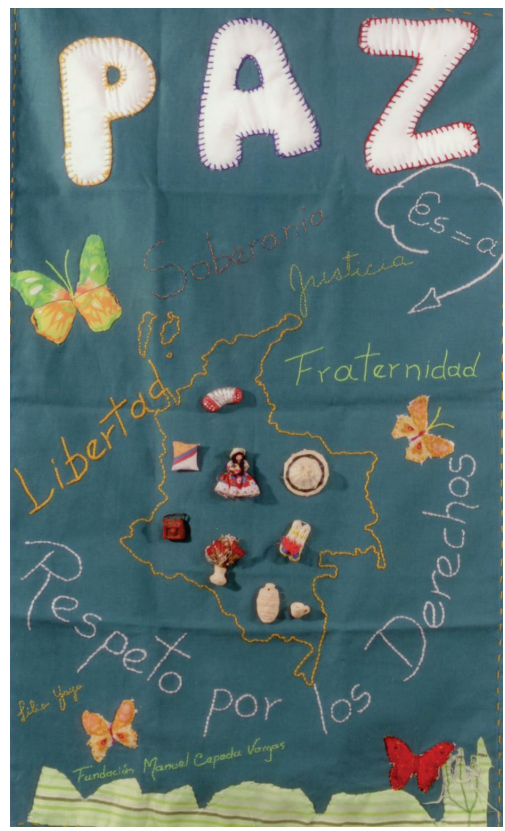




\section{Historia de vida de Germán Humberto Rincón Perfetti}

Entrevista elaborada por: ANDREA PAOLA BUITRAGO ROJAS

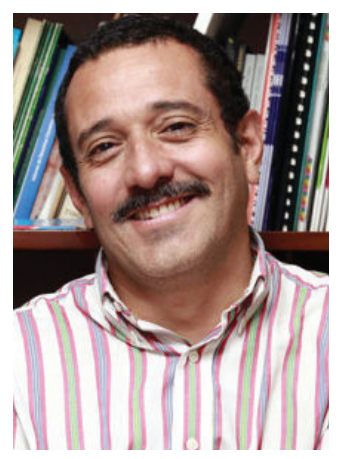

"Defender sus propios derechos desde mi propia necesidad"

\section{GERMÁN HUMBERTO RINCÓN PERFETTI}

$\mathrm{N}$ ací el 13 de julio de 1961. La historia del lugar de mi nacimiento es relevante porque mi madre y mi padre tuvieron primero una niña en Villavicencio. Esa niña murió. Luego, yo fui su hijo, y por eso buscaron todos los cuidados durante la maternidad y el parto, se trasladaron a Bogotá, a la Clínica David Restrepo en Chapinero, que no existe hoy y las instalaciones actualmente son la estación de bomberos de Chapinero. Mi bautizo fue en la iglesia de Lourdes en Chapinero, por lo que es anecdótico haber nacido y haber sido bautizado en Chapinero, ya que para el movimiento LGBTI este barrio es un referente histórico.

Estudié una parte de la primaria en Villavicencio y la otra en Bogotá, el bachillerato lo estudié en Neiva y en Bogotá, el último año lo estudié en el Gimnasio Militar de la Fuerza Aérea, ubicado en Bogotá. Luego, ingresé a la Universidad a estudiar Arquitectura, donde duré solamente un semestre ya que decidí abandonar la carrera. Paradójicamente, la asignatura que más me gustó fue Antropología, por lo que me incliné por las Humanidades y decidí estudiar Derecho.

Ingresé a estudiar Derecho en la Universidad Militar Nueva Granada, porque, como mi padre era militar pensionado, me otorgaron 
un descuento. Estudié en la noche toda mi carrera mientras que en el día trabajaba en los juzgados. Cuando me gradué, busqué continuar mi activismo realizado durante la juventud en el Colegio Católico Salesiano, donde presté servicio entusiasta de apostolado, realizando misiones de oración carismática, por lo que empecé a buscar servicios sociales en el barrio Toberín, ya que allí había una asociación de comerciantes e industriales que se encargaban de pavimentar vías. Presté servicio de asesoría jurídica gratuito pero nadie fue. Luego, me acerqué al obispo de Usaquén con la Asociación de Erradicación de Tugurios pero tampoco tuve respuesta. Finalmente, llegué a la Liga contra el sIDA donde defendí el derecho a la salud vinculado a un grupo que se llamaba "Proyecto Wanda”, que buscaba la prevención del SIDA en hombres que tenían sexo con otros hombres, por este camino empecé a realizar tutelas que buscaban la protección del derecho a la salud de los homosexuales.

El primer caso que asumí fue sobre un comercial de televisión que vendía condones a la población homosexual, ya que en el comercial salían dos hombres besándose en la plaza de Bolívar y por este hecho fue censurado el comercial. Allí, desempeñé algo que sin saber sería un litigio estratégico, ya que esta tutela llegó por revisión a la Corte Constitucional, quien la negó, pero la jurisprudencia que se desarrolló a favor de los homosexuales fue un avance relevante para otros casos.

Para esta época, se iniciaron grupos de lesbianas y de gays. Estaba el grupo Omegas, Triángulo negro, Equiláteros, etc., con los cuales planteé la creación de una semana cultural y deportiva, idea que retomé de unos amigos con discapacidad, que participaban en distintos eventos culturales. Con el apoyo de la parroquia de Santa Teresita (ubicada en la calle 44 con 17 en Bogotá), ya que nosotros no teníamos recursos económicos, se desarrolló la celebración del 28 de junio, el día Internacional del Orgullo LGBT. Ese día, cada grupo se encargó de realizar actividades que fueron agendadas y publicadas en lugares de homosocialización. Así fue como se creó la primera marcha, a la que salimos informalmente a la ciclovía con bicicletas y patines. El segundo año fue más estratégico, salimos a pie y pedimos los permisos legales. El tercer año, marchamos de nuevo pero decidimos salir al finalizar la ciclovía, para darle mayor visibilidad por la publicidad que le daban los medios de comunicación. 
Inicialmente, el recorrido de la marcha fue por la zona del gueto, es decir, del parque nacional a la calle 72 , de la calle 72 al parque nacional, del parque nacional a la Plaza de Lourdes y luego a la calle 72, pero en seguida se planteó que el lugar con mayor importancia simbólica era la Plaza de Bolívar, por lo que se cambió la ruta partiendo del Parque Nacional y dando un cierre en la plaza de Bolívar. En las primeras marchas, no teníamos ni plata, ni tarimas por lo que me subí a un árbol y agradecí a las personas por la participación.

Durante una de las marchas, se presentó la coacción de un grupo de skinhead que amenazaba con violentarla, por lo que nuestra organización previa fue importante, ya que nuestra marcha era legal y con el grupo de agentes de la policía se logró la organización encubierta de policías como manifestantes, que recogieron al grupo de skinhead antes de que violentaran la marcha. En las primeras marchas, nos acompañaba el ESMAD (Escuadrón Móvil Antidisturbios) ya que nos veían como grupos revolucionarios pero luego de conocer el movimiento de la marcha nos terminaron por acompañar agentes civiles.

En nuestra historia como organización, buscamos alianzas políticas, y por eso, en el primer periodo electoral de Álvaro Uribe Vélez, nos reunimos con Luis Eduardo Garzón quien sería candidato a la presidencia. Lo invitamos a él y a Carlos Gaviria, que para esa época se estaba postulando para el Senado, en un Bar Gay, ubicado en la tercera con Caracas y les dijimos: "No queremos ni puestos ni contratos, sino la política pública". Nos comprometimos a votar por ellos y ellos se comprometieron a elaborar una política pública. Les pedimos que firmaran y Carlos Gaviria dijo que no firmaba ya que él siempre en sus sentencias había apoyado nuestras causas. Luego, vimos con sorpresa como Luis Eduardo Garzón cambió y se lanzó a la Alcaldía de Bogotá, allí nos cumplió el Acuerdo programático, se reunió con toda la alcaldía y con nosotros con el fin de ver qué necesitábamos. Fuimos cuatro personas y le pedimos la política pública, capacitación, apoyo en las marchas y eliminar la discriminación. Luis Eduardo fue a todas las marchas, él siempre hablaba al inicio o al final, fue la primera vez que un alcalde nos daba su apoyo.

El 28 de junio, siendo alcalde, dio la apertura a la marcha en el Theatrón, donde dio un discurso y habló de la adopción, mostrándose 
a favor, por lo que fue puesto en escándalo público por los medios de comunicación. Finalmente, elaboró el Proyecto de Acuerdo de Política Pública y lo presentó ante el Consejo y allí fue rechazado por grupos políticos cristianos. El 28 de diciembre, tres días antes de cerrar su administración, firmó la política pública LGBT, que luego, en la siguiente administración, fue aprobada por el Concejo. En adelante, los cierres de las marchas en la Plaza de Bolívar siempre tuvieron apoyo económico, incluso hasta hoy en su edición 23. A estas celebraciones, han llegado muchas personas pero en la actualidad yo ya no lidero esos espacios. Creo que no debería quedarme sentado atornillado, ya que hoy hay otras personas con más creatividad por lo que me dedico al activismo judicial, en el ejercicio de mi profesión como abogado.

El tema de partidos políticos es otro escenario en el que hemos incluido nuestro discurso en otro escenario de poder. Inicialmente, tuvimos incidencia en la izquierda cuando se gestó la formación del Polo Democrático Alternativo. Allí, estuvimos presentes: Blanca Durán, Angélica Lozano, Daniel García Peña y yo, me falta uno que no recuerdo quién era, porque éramos cinco. Esta participación nos permitió afirmar que aquí existimos, logrando unas cuotas a favor de indígenas, afros, jóvenes y LGBT, lo que nos permitió ubicarnos con representación en la Junta Nacional del Partido. Otros partidos políticos, con el tiempo, también nos dieron su respaldo, como fue el caso de los liberales y del Verde.

Piedad Córdoba tenía una estrategia política. Ella se ubicaba primero en las listas, luego se ponía un afrodescendiente, un pensionado y un LGBTI, logrando así un apoyo conjunto. Yo me lancé como representante a la Cámara de Representantes, Piedad quedó pero yo no. Posteriormente, me llamaron del Polo Democrático y me hicieron la invitación de lanzarme y no quedé. Luego, fui llamado al Concejo, no sabía qué hacer por lo que consulté con mi familia y me dijeron que si no requería de dinero y no tenía nada que perder lo hiciera, por lo que me volví a lanzar y tampoco quedé. En este proceso, hicieron parte Manuel José Bermúdez y Manuel Velandia. Sin embargo, en el campo político, fue electa Erika del Río, algo muy importante, porque fue la primera trans electa. Pienso que avanzar dentro de partidos políticos permitió dar visibilidad popular que se refleja hoy en el espacio público. 


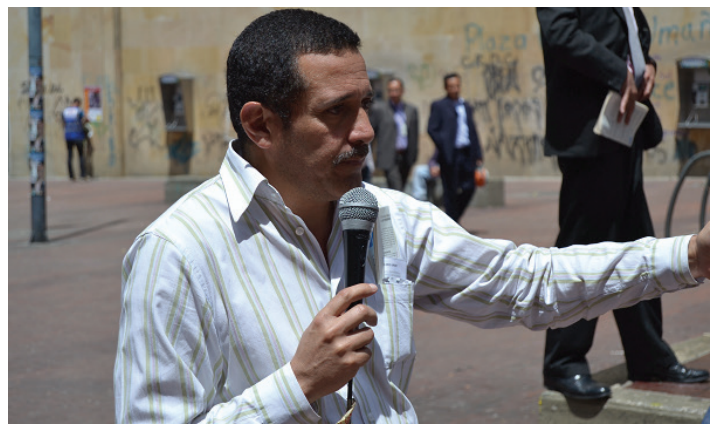

Germán Humberto Perffeti en la Cátedra Libre y abierta: Población LGBTi y Derechos Humanos el 11 de febrero de 2014 en la Plaza Eduardo Umaña Mendoza

En conclusión, la política pública LGBTI fue una apertura que nos ha dado muchas ganancias en tan poco tiempo, hemos avanzado mucho más que otras organizaciones y movimientos sociales, con un menor número de muertos.

Con la Política Pública, tuvimos distintas respuestas, como fue la del rector de la Universidad Gran Colombia que decía que era un proyecto importado. Pero llegó Virgilio Barco Isakson, Andrew Dier, Carlos Iván García y Marcela Sánchez e integramos Colombia Diversa que es hoy un referente esencial para la defensa de los derechos humanos, reafianzando la Política Pública.

En el escenario de paz, recuerdo mi participación en el proyecto "Planeta Paz" donde se buscó que los distintos sectores y movimientos sociales se organizaran y empezaran a pensar en la paz de Colombia. Se incluían a adultos mayores, mujeres, indígenas, afrodescendientes y LGBT. Se planteó trabajar en paz en Colombia incluyendo la participación LGBT. Fue en Maloka donde hablamos tres personas: una mujer, otro muchacho y yo. Fue allí donde se dio el verdadero nacimiento del Movimiento Social LGBTI. Allí, se hizo un reconocimiento de distintos movimientos sociales en Colombia: Popayán, Medellín y la Costa pensando en términos de paz, donde posteriormente se realizaron otros eventos. El Movimiento Social LGBTI buscó construir un discurso del cuerpo, ya que este es el primer escenario para construir la paz. Las memorias de nuestro trabajo se construyeron en políticas públicas, visibles en marchas departamentales, que me impresiona la extensión, ya que al inicio éramos muy poquitos y hoy somos muchos 
y con mucha fuerza. Ha habido marchas en Salento, Bello, Mompox, la Costa, Pasto y hasta en Tunja, que recogen este legado. Hoy en día, me impresiona todo esto, ya que nunca pensé que fuéramos a llegar a lo que hemos llegado. Hoy, sigo llevando casos de tutelas, proyectos de ley con un activismo muy propio ligado a mi profesión.

En el ejercicio de mi profesión, destaco el caso de la adopción y del matrimonio, que no estaba inicialmente en la agenda, pero un día acudieron a mi oficina dos mamás lesbianas, Ana y Verónica. Una de ellas con una hija biológica por inseminación artificial en el extranjero, cuando se acercaron planteando el tema de la adopción les dije que lo pensaran bien porque habían pocas probabilidades de lograrlo. Fue una tutela muy bien presentada, y fue una sorpresa encontrar que en primera instancia el fallo salió a favor en un Juzgado de Rio Negro, por el lugar de la competencia, luego se dio lugar a la apelación por parte del exprocurador Ordoñez, y salió el fallo favorable por parte del Tribunal de Antioquia. Más tarde la Corte lo revisó y todo terminó siendo exitoso.

Otro proceso fue sobre el matrimonio y el tema pensional. Se hizo una alianza entre Felipe Montoya y la Universidad de los Andes, para avanzar sobre la materia. Duró dos años en el Congreso para cambiar la realidad del matrimonio y a pesar de eso, las notarías se inventaron un documento para cumplir la sentencia que no correspondía con un matrimonio. Por lo que presenté tutelas contra el presidente del Colegio de Notarios, y la Corte Constitucional, por vía de revisión, terminó expidiendo una sentencia que avaló el matrimonio igualitario.

Un logro enorme fue la figura del "Oficial de Enlace" que fue copiada del Ciclo Rosa, de otras ciudades, Toronto y Londres, cuya función es ser un puente entre la población LGBTI y la policía, figura que fue incluida por Luis Eduardo Garzón y que Colombia Diversa instó para que la Policía Nacional la pusiera en todas las regiones. Fue impresionante ver reunido a un gran grupo de la policía con nosotros, siendo una minoría de activistas, con el fin de explicarles nuestras necesidades en el ejercicio de sus funciones como oficiales de enlace. Esto es muestra del activismo, que hoy hay mucho, siendo este otro motivo para ocuparme en el litigio.

En este escenario de activismo y de ejercicio profesional, puedo afirmar que nunca he tenido amenazas, aunque algunos amigos cercanos 
sí sufrieron venganzas y desplazamientos sobre todo en las regiones rurales, pero no estuve frente a esos casos.

Hoy puedo decir que Colombia está mucho más avanzada gracias a la Corte Constitucional que, en más de 120 sentencias, ha fallado en favor de las personas LGBTI que permiten un progreso, a diferencia del ejecutivo y el legislativo. Sin embargo, los alcances están en el papel. Falta la transformación estructural y social y la condena de fundamentalismos religiosos cristianos que, junto al exprocurador, se han opuesto a nuestro movimiento. Es imposible creer en un país como el nuestro, con un Estado Social de Derecho garantista, donde existe una Procuraduría para defender los derechos de los ciudadanos y la Tutela, que haya un procurador que haga uso de la tutela para violentar nuestros derechos, eso es algo inconstitucional.

En las cárceles también se han realizado avances. Fue el asunto del Patio Nuevo Milenio donde se ubica a la población con viH, a quienes no los dejaban salir a trabajar bajo el argumento de evitar un contagio, lo que tenía efectos sobre la rebaja de pena ya que quienes acceden a trabajar en los talleres pueden tener una rebaja de pena. Fui a visitarlo y ante esta situación se puso una Acción de Tutela con resultado favorable porque se les permitió salir a los talleres a tener capacitaciones.

En las Fuerzas Militares, se ubica la inclusión que resultó del litigio de Sandra Yaneth Mora Morales, perteneciente a Triángulo Negro, que había sido destituida de su cargo por su orientación sexual. Lo que dejó un precedente importante en la carrera de la Policía Nacional frente a hechos de exclusión en el marco laboral. Otro avance hacia la inclusión se presentó en relación con el Estatuto Docente donde se ubicaba como causal de mala conducta una orientación sexual diversa, lo que hizo que, por primera vez, se realizara una audiencia pública en la Corte, donde participó una docente con su rostro cubierto, que narró todas las atrocidades que se cometían en su institución por esta causa. El resultado fue una sentencia favorable, muy importante para estos casos de exclusión.

En el escenario del Paramilitarismo y de la Guerrilla, se declara objetivo militar a la población LGBT, esta es una práctica tanto de la derecha como de la izquierda, por la intolerancia y el control de la población, que se originaba en la búsqueda del control de los cuerpos, de la 
hora de entrar y salir de la vivienda, de la hora de dormir, del uso de la ropa, de la identidad sexual. Ligado a esto, se presentan panfletos en los que se señalan personas que van a matar, personas que van a violar, sobre todo población trans, que se ven obligadas a desplazarse.

Durante este trabajo ligado a los derechos humanos, puedo decir que aprendí de mi maestra Amanda Romero, y digo maestra, no porque fuera mi profesora en la Universidad, ya que allí no tuve clases de nada de esto, sino porque es mi maestra de la vida que me enseñó a defender mis derechos desde mi propia necesidad, ya que solo así entiendo totalmente la situación.

En la actualidad, puedo decir que me encuentro contento con los resultados y avances de la población LGBTI, ya que repito éramos muy pocos y me impresiona la cantidad que somos ahora y lo mucho que hemos avanzado, de modo que mi trabajo de defensa y litigio en el ejercicio de acciones legales lo estoy extendiendo también para otros sectores de la población, es el caso de camas pediátricas, adultos mayores, acueductos veredales, comunidades vulnerables, donde desarrollo todo ese aprendizaje a otros escenarios haciendo lo que me gusta.

GERMÁN HUMBERTO RINCÓN PERFETTI

\section{La construcción de la paz desde abajo en las historias de vida relatadas}

La anterior reconstrucción de las historias de vida tiene por objeto ubicar en la vida de los líderes los elementos que, a lo largo de la historia de los movimientos sociales, se pudieron ubicar como directrices que orientaran el movimiento, atendiendo a la discriminación y a los escenarios que el conflicto armado interno ha proporcionado sobre la vida de las personas. En este sentido, es preciso examinar sistemáticamente las teorías sobre la paz y los elementos del derecho a la paz presentes en la vida e historia de estos líderes, para poder determinar las características para constituir una argumentación y un análisis preciso para elaborar la propuesta del Derecho Humano a la Paz en Colombia desde abajo, objeto de esta investigación. 


\section{Paz Positiva}

Transformación de un conflicto en el escenario estructural y cultural, permitiendo el desarrollo y crecimiento de una comunidad.

\section{Marco Tulio Yate Yara}

En la historia de vida del Señor Yate Yara, se destaca la identidad indígena en los principios y los valores colectivos y comunitarios del pueblo Pijao, y las enseñanzas de liderazgo de su padre, lo que le permitieron construir una propuesta de reconocimiento del Pueblo Pijao en la Capital. El estatus obtenido como resultado del proceso de desplazamiento que la violencia produjo en su región. Esta apuesta permitió adelantar procesos de fortalecimiento y solidaridad con las personas de su comunidad, y personas externas que viven en situaciones económicas precarias donde la violencia estructural permanece. Es por ello que su propuesta es solo un inicio de transformación de un conflicto por un camino de desarrollo de la Paz positiva, propuesta por Galtung, donde las posibilidades de cobertura de las necesidades básicas, como es la alimentación con un enfoque diferencial que permita la práctica de la gastronomía tradicional, es una manifestación de transformación de la violencia cultural y estructural en el exterior de su comunidad.

\section{Marcelina Cundumi Díaz}

El caso de la señora Cundumi señala el aprendizaje del liderazgo de su padre, que buscó la transformación de la violencia estructural y cultural, lo que permitió a su familia y a su comunidad la búsqueda de construcción de una paz positiva. Dadas las circunstancias estructurales y culturales de la sociedad colombiana, aún falta mucho por constituirse este camino. Ella, en su defensa de los derechos humanos, ha buscado adelantar procesos de reconocimiento y reparación de los daños que ha sufrido su comunidad, y construir posibilidades que permitan la alimentación, la educación, la salud y el desarrollo digno de su comunidad, y la construcción de justicia, destacando su actual participación en la JEP.

\section{Rosa Lilia Yaya Cuervo}

En la vida de la señora Yaya, se destaca el liderazgo de su padre, de quien aprendió a buscar vías de trasformación de los conflictos colombianos como posibilidad de disposición de la paz positiva desde una perspectiva política. Sin embargo, el liderazgo de su difunto padre fue entorpecido, lo que debilitó su labor social, lo que condujo a que la señora Yaya buscara constituir procesos de memoria, verdad, historia y justicia como puntos de partida para construir la paz positiva.

\section{Germán Humberto Rincón Perffeti}

El activismo judicial que desempeña el señor Germán Humberto Rincón Perffeti permite ubicar una posibilidad de trasformación del escenario de la exclusión estructural, política, económica y cultural de la comunidad LGBTI, porque en el ejercicio judicial, logró transformar la jurisprudencia colombiana afianzando el reconocimiento y eliminando la discriminación. El litigio se convierte en el sentido constante de su vida, es el propósito y el espacio en el cual ha desarrollado una representación desde debajo de las comunidades vulnerables. 


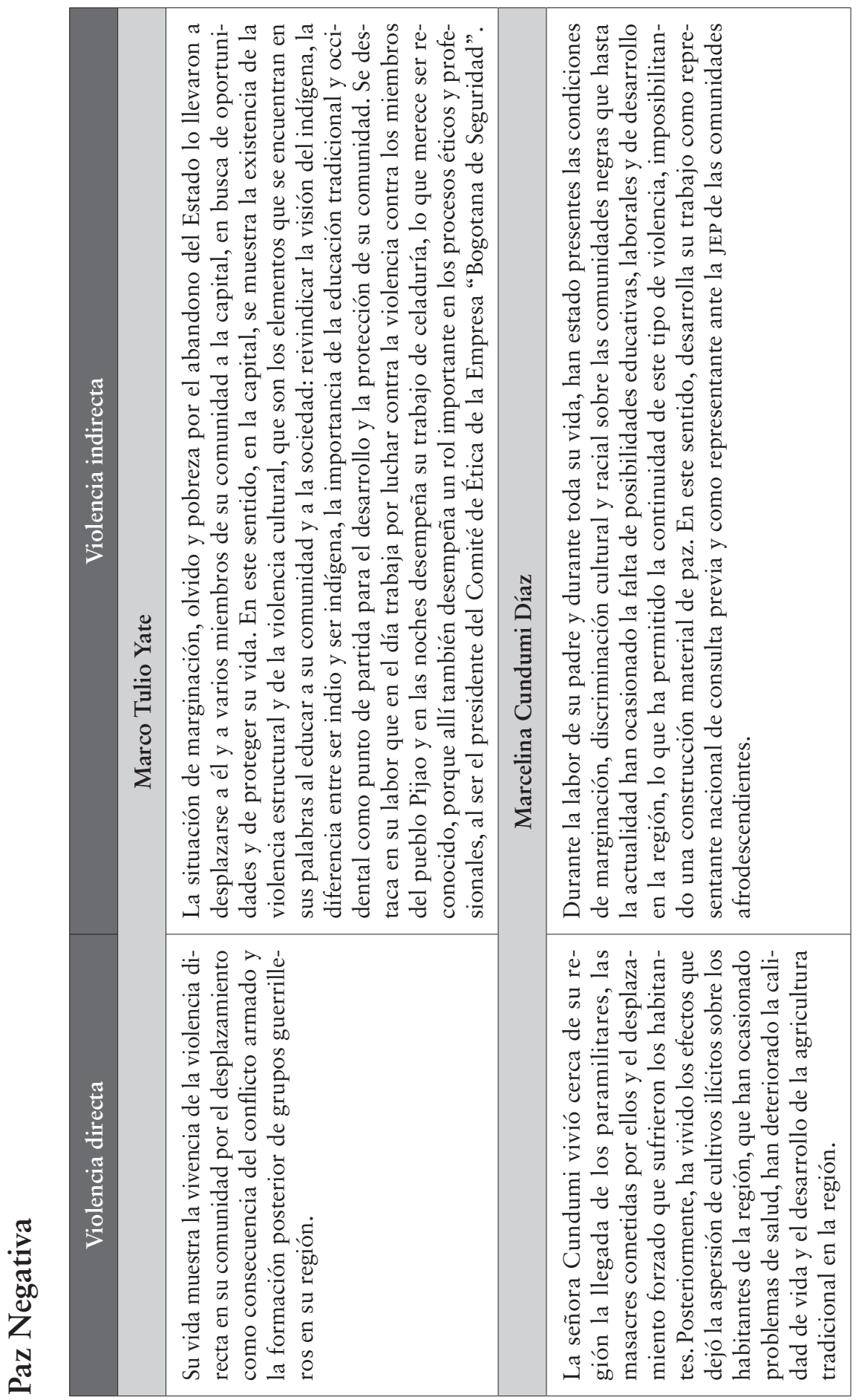




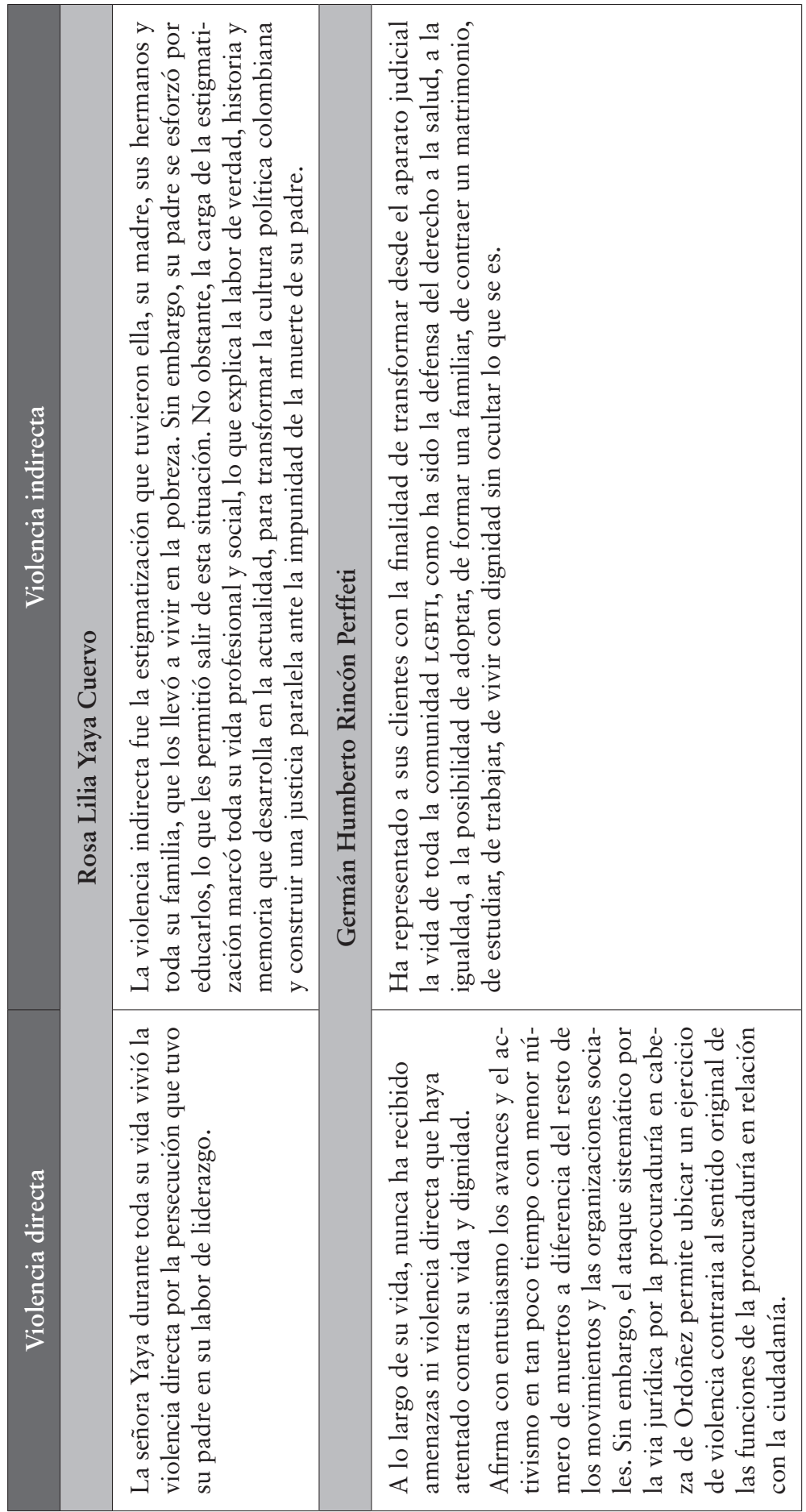




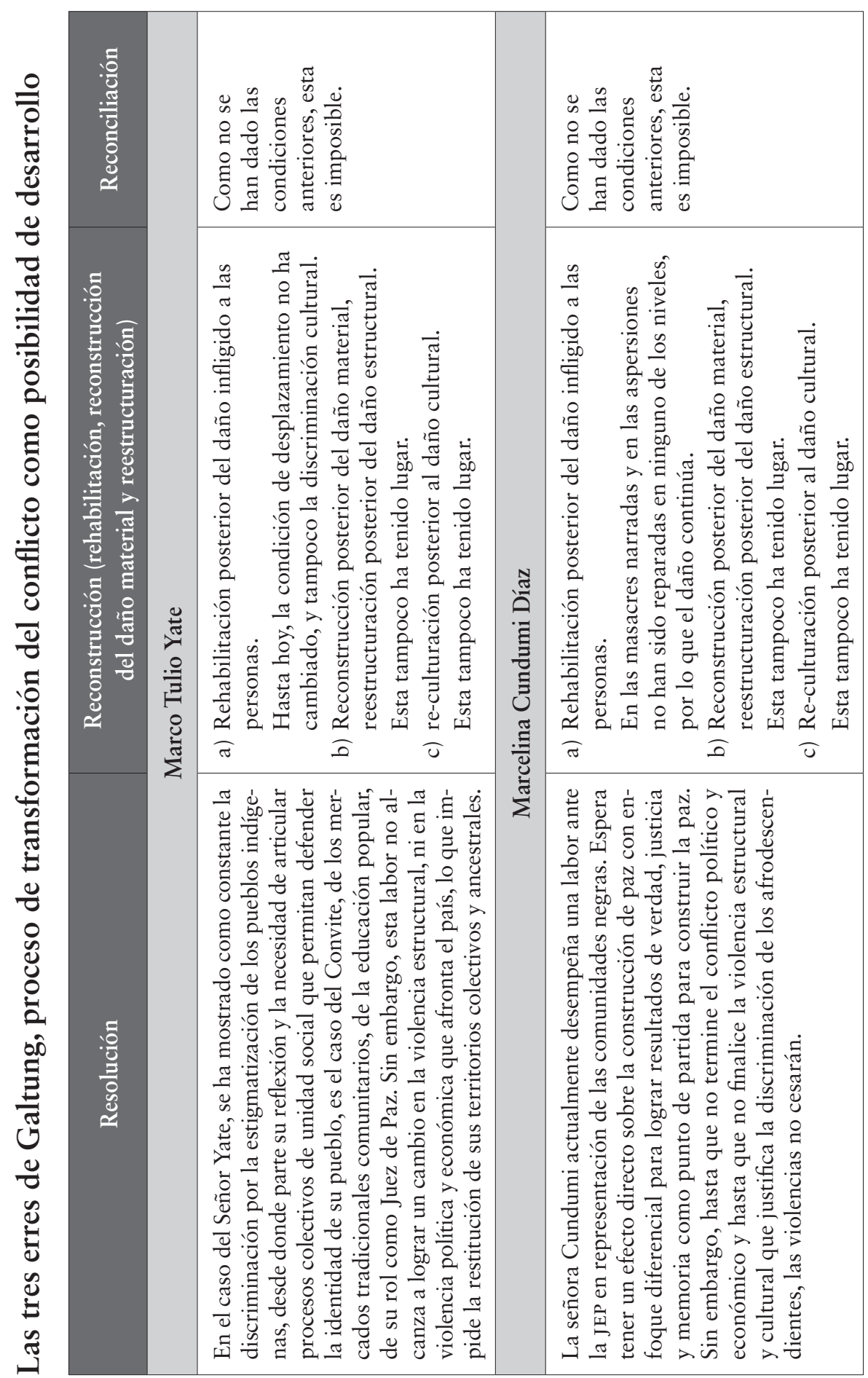




\begin{tabular}{|c|c|c|c|c|}
\hline 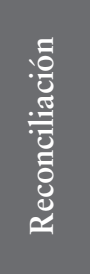 & & 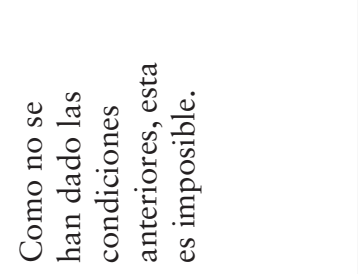 & & 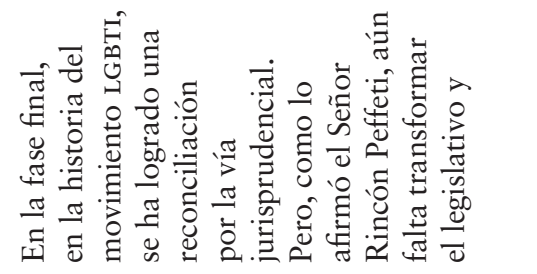 \\
\hline 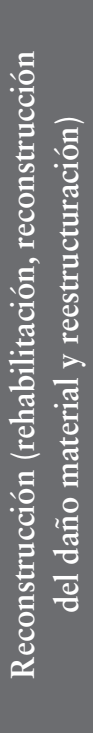 & 茪 & 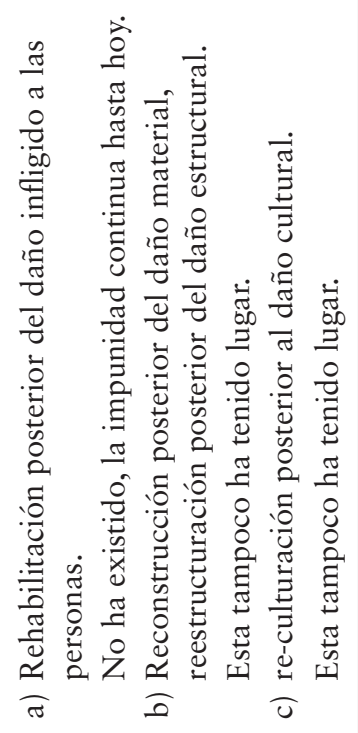 & 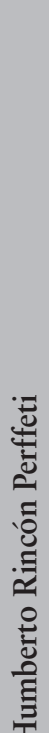 & 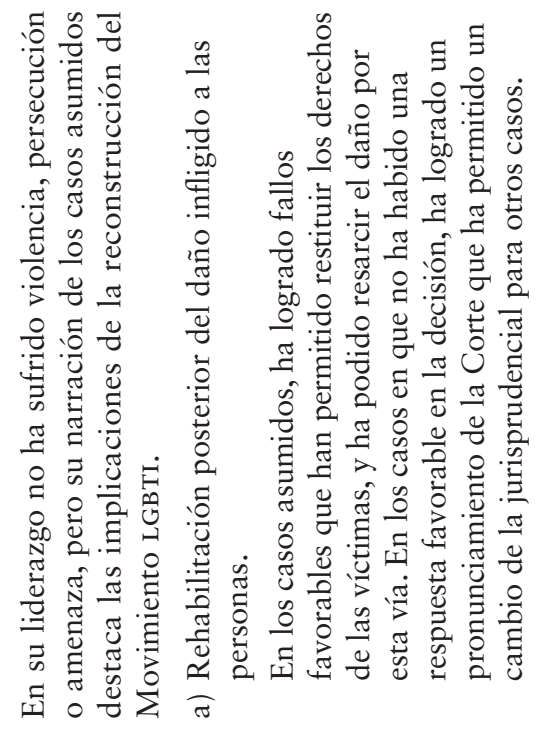 \\
\hline 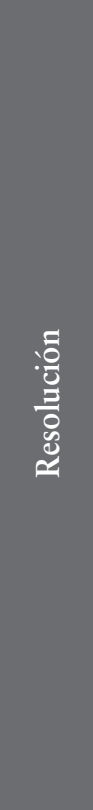 & 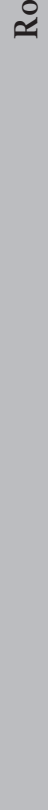 & 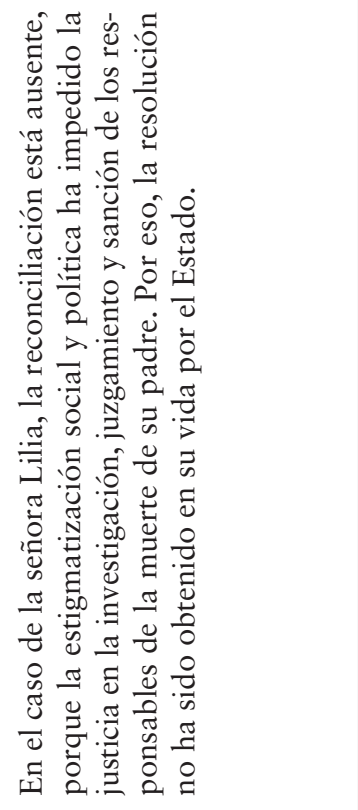 & 预 & 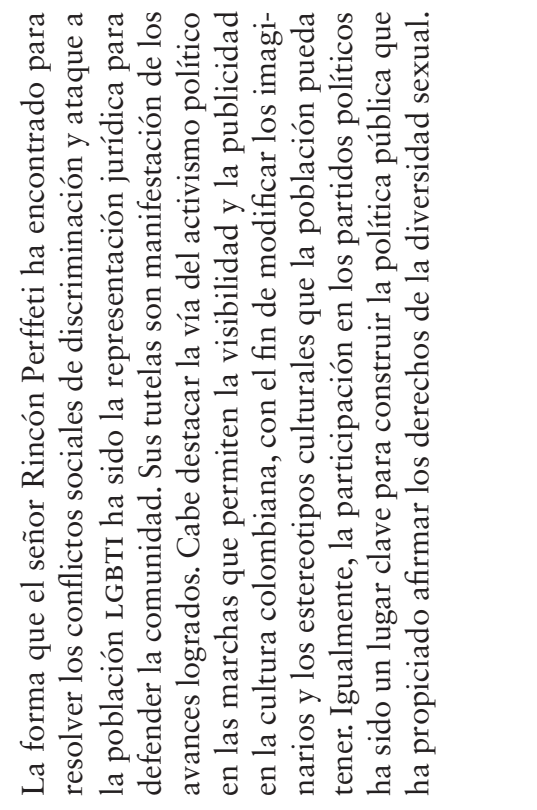 \\
\hline
\end{tabular}



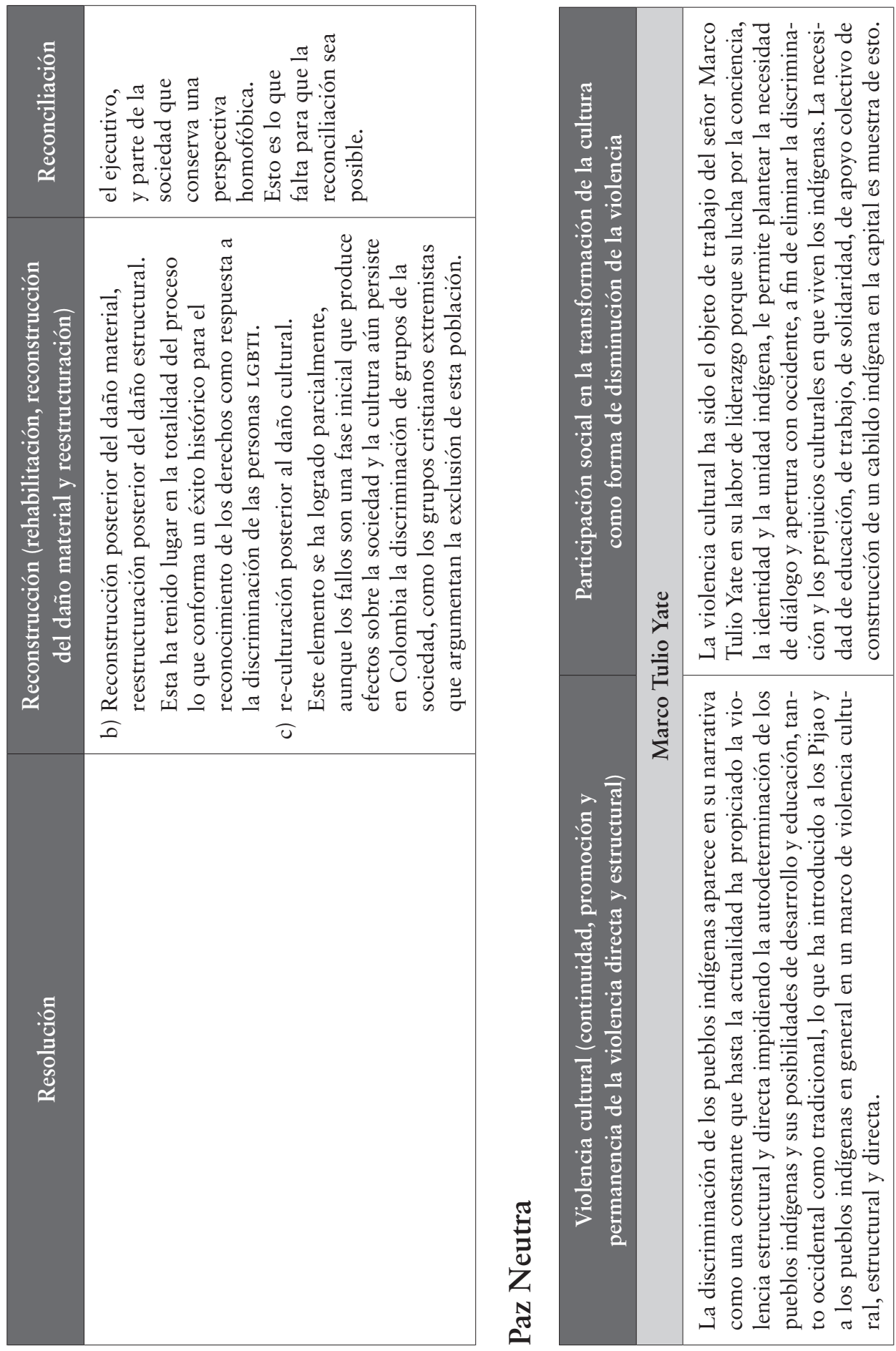


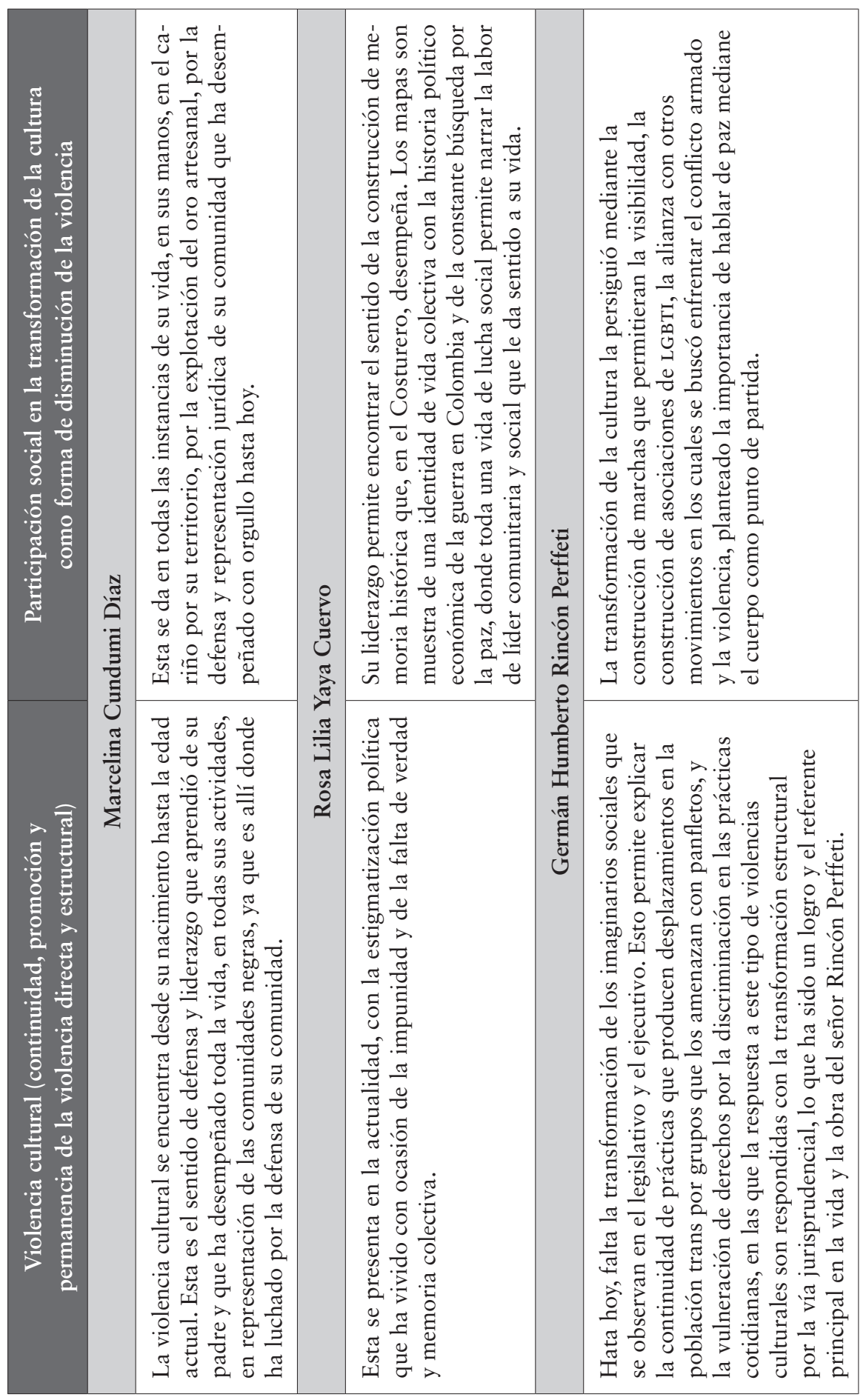




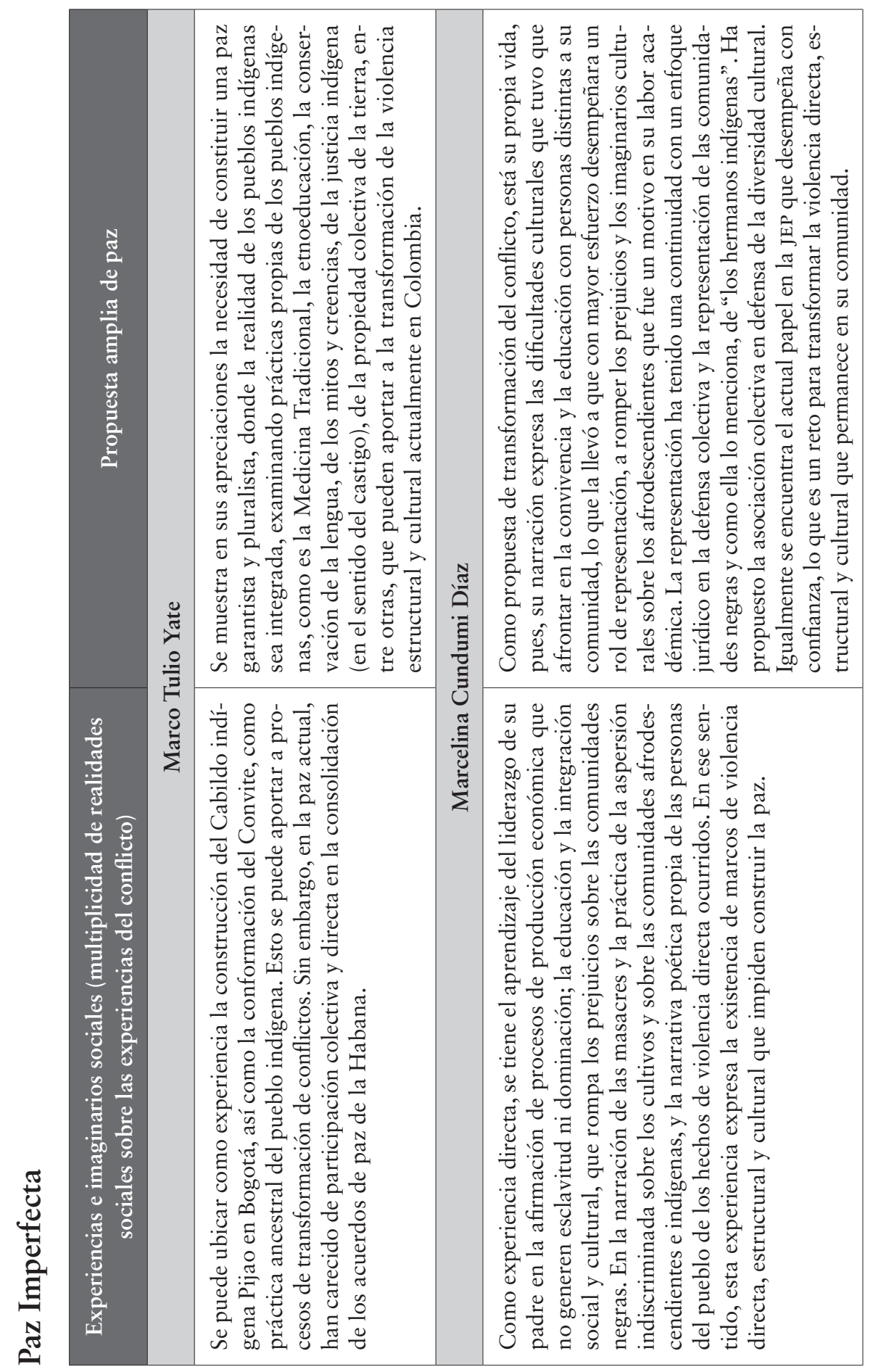




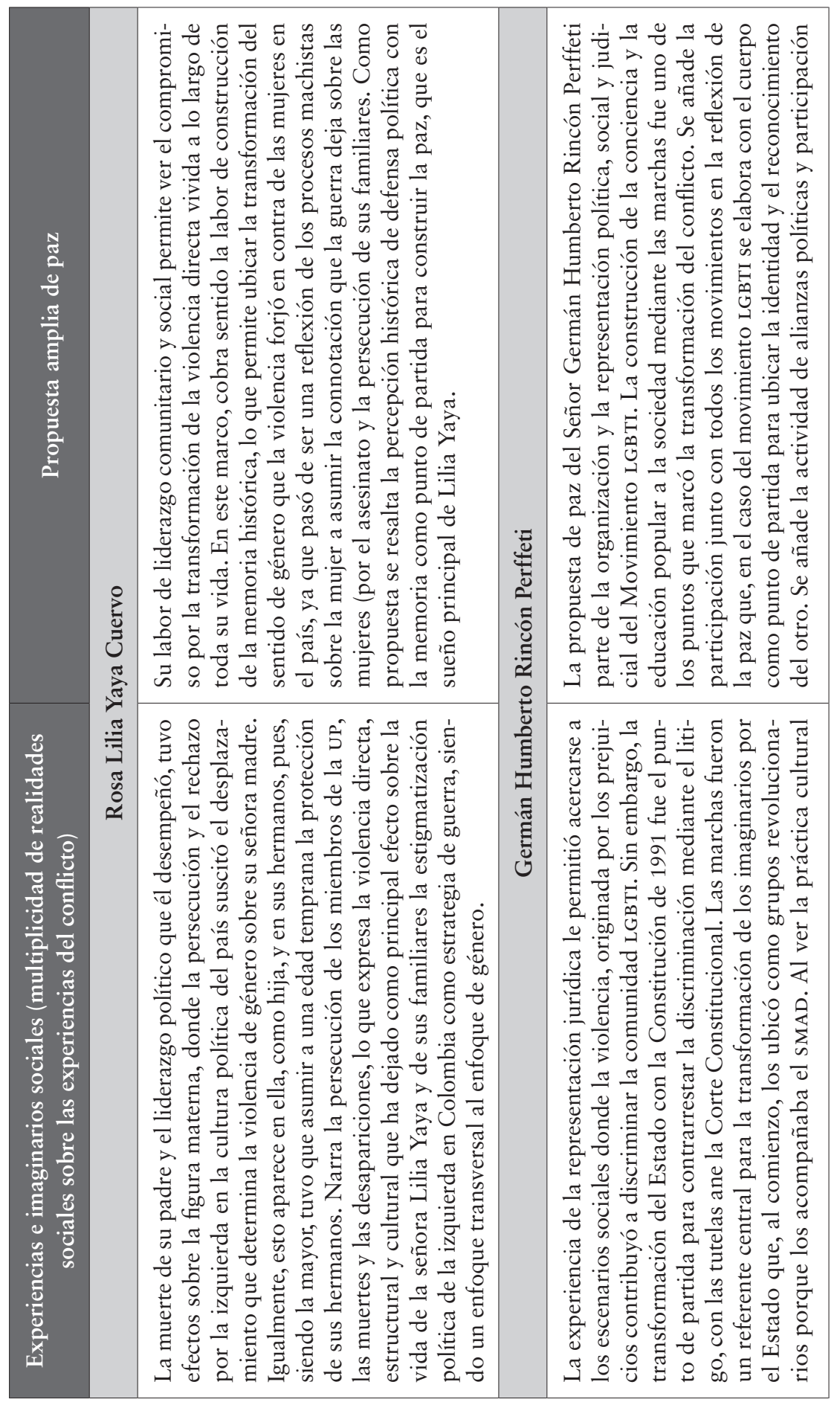



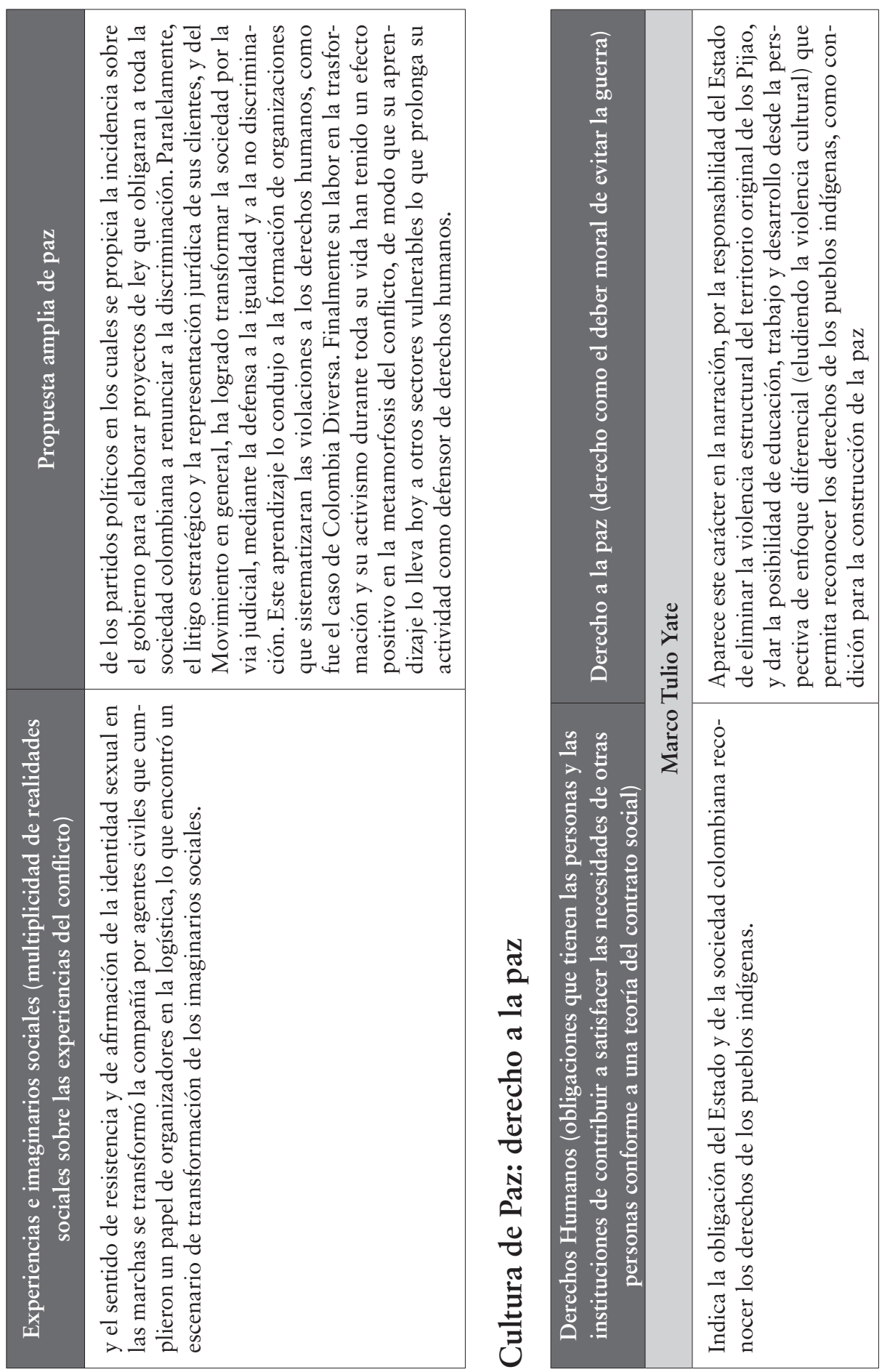


\begin{tabular}{|c|c|c|c|c|}
\hline 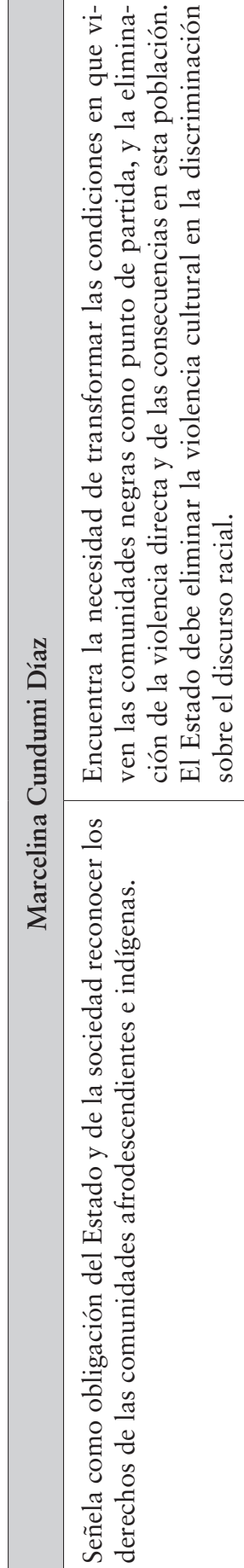 & 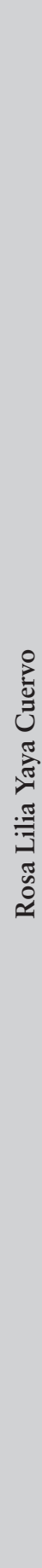 & 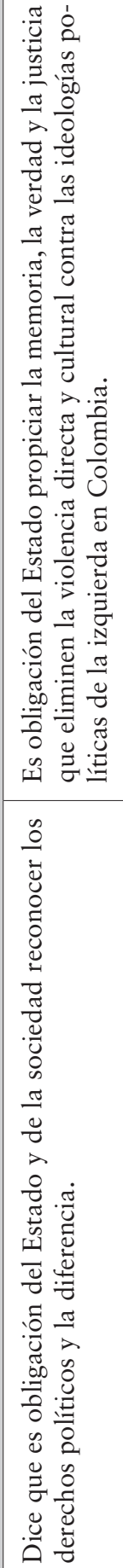 & 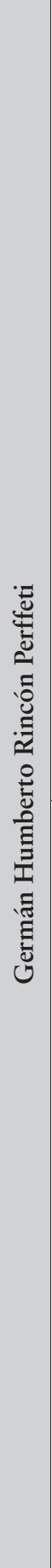 & 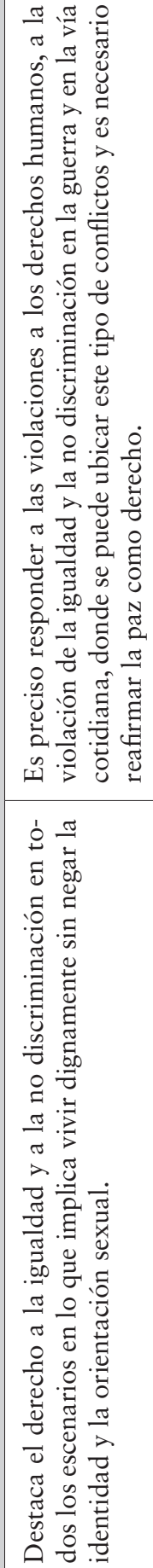 \\
\hline
\end{tabular}




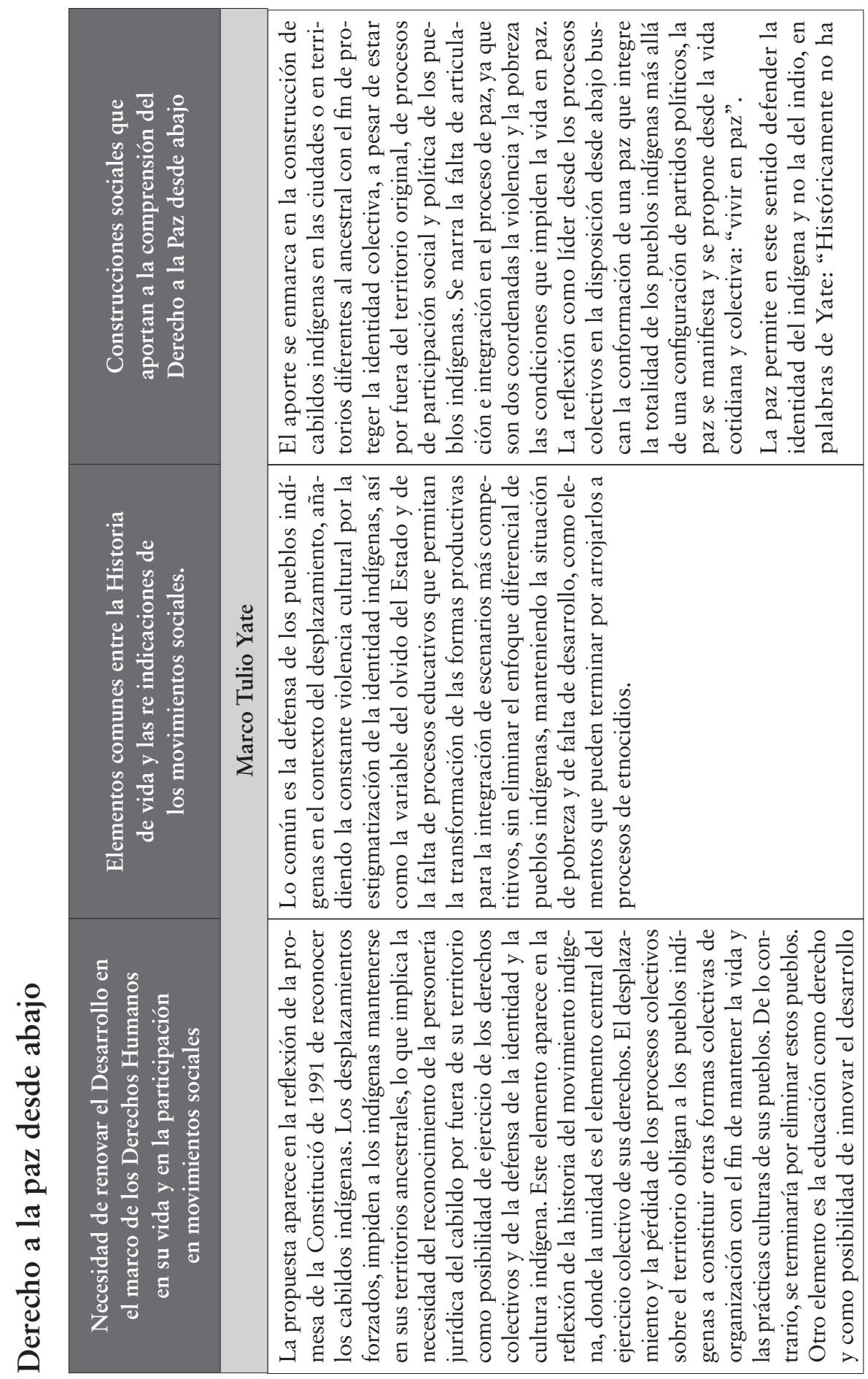




\begin{tabular}{|c|c|c|c|}
\hline 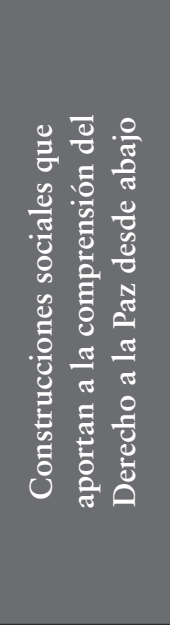 & 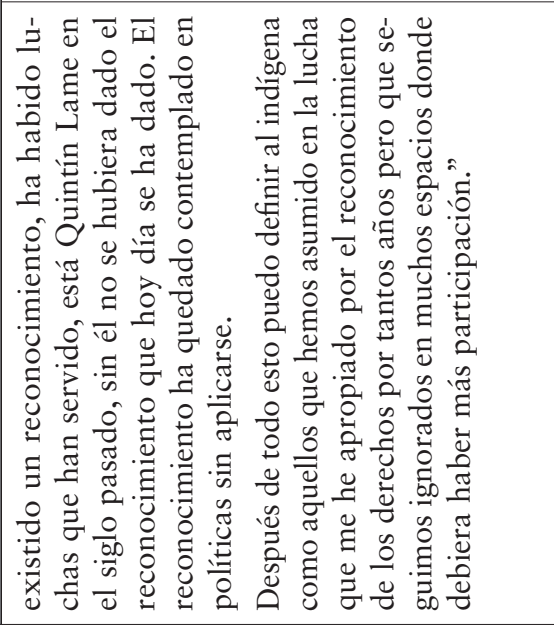 & & 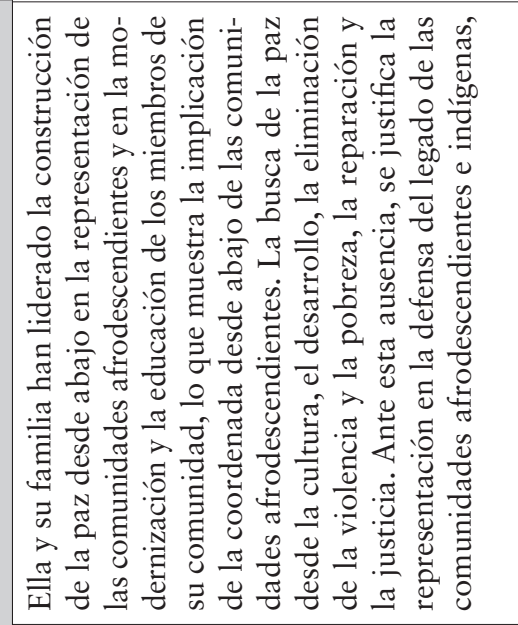 \\
\hline 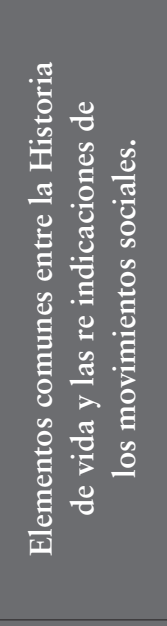 & & 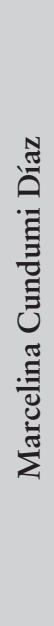 & 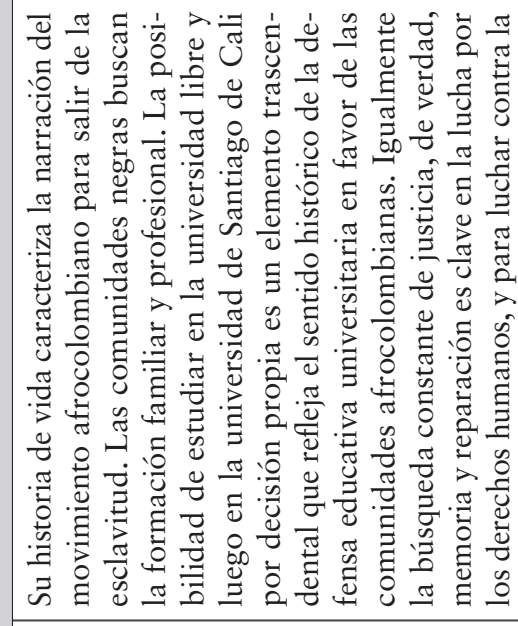 \\
\hline 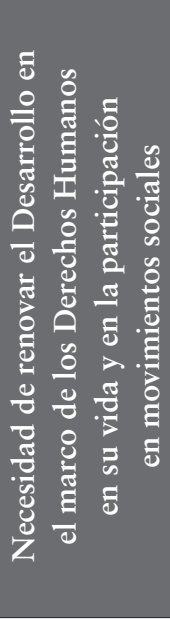 & 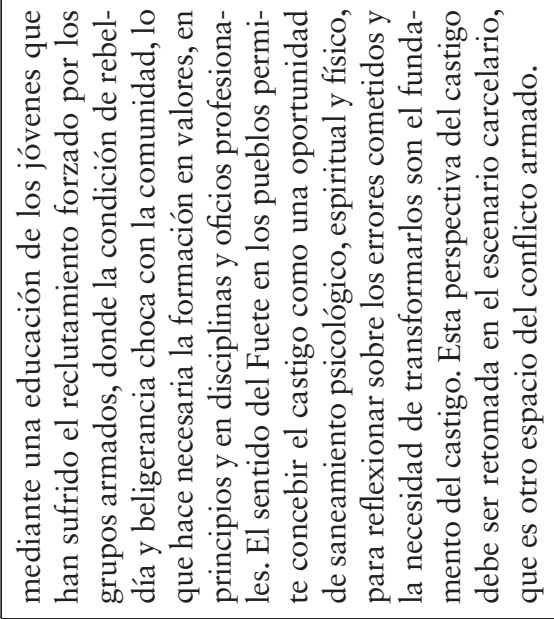 & & 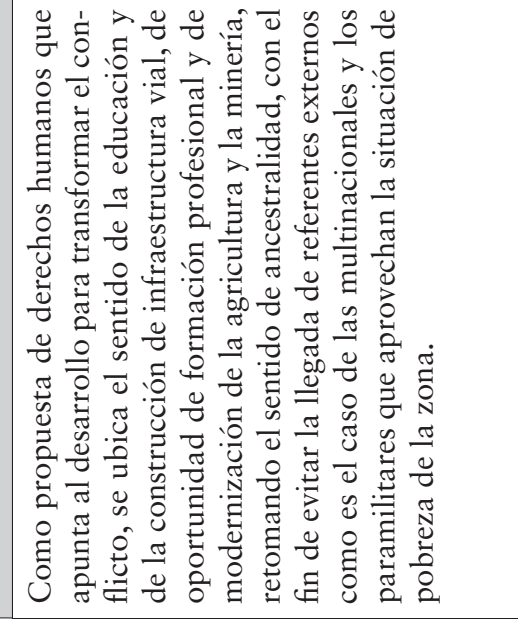 \\
\hline
\end{tabular}




\begin{tabular}{|c|c|c|c|c|}
\hline 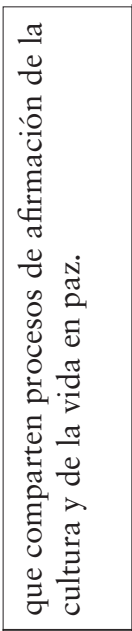 & \multirow{3}{*}{ 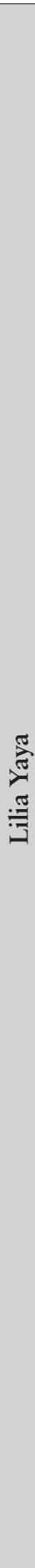 } & 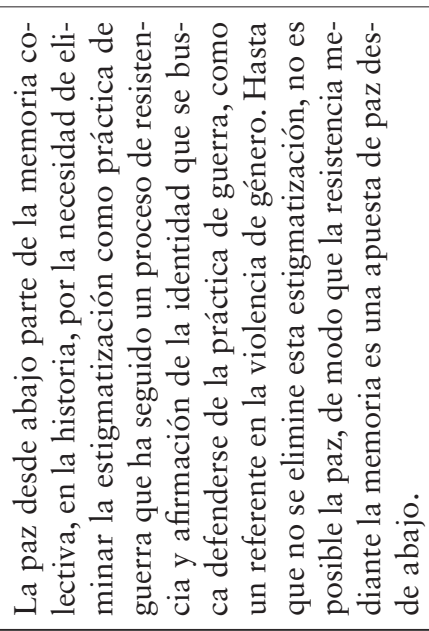 & \multirow{3}{*}{ 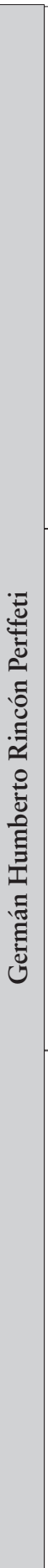 } & 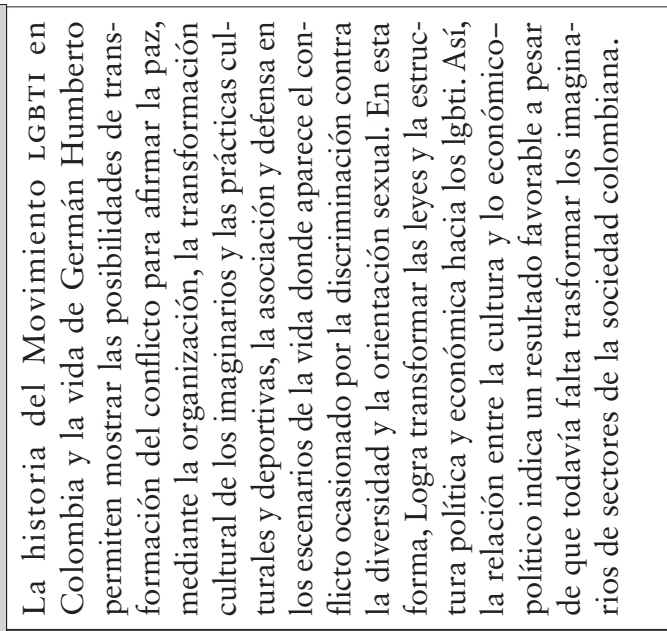 \\
\hline \multirow[t]{2}{*}{ 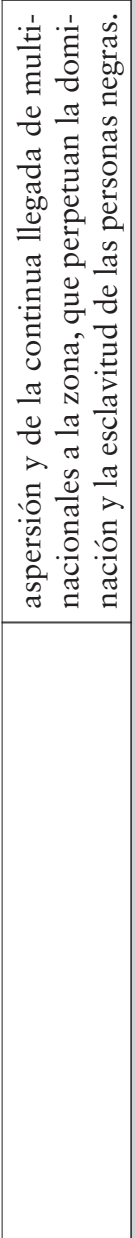 } & & 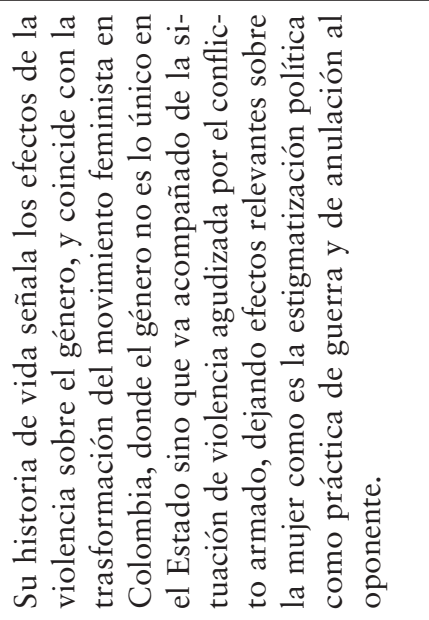 & & 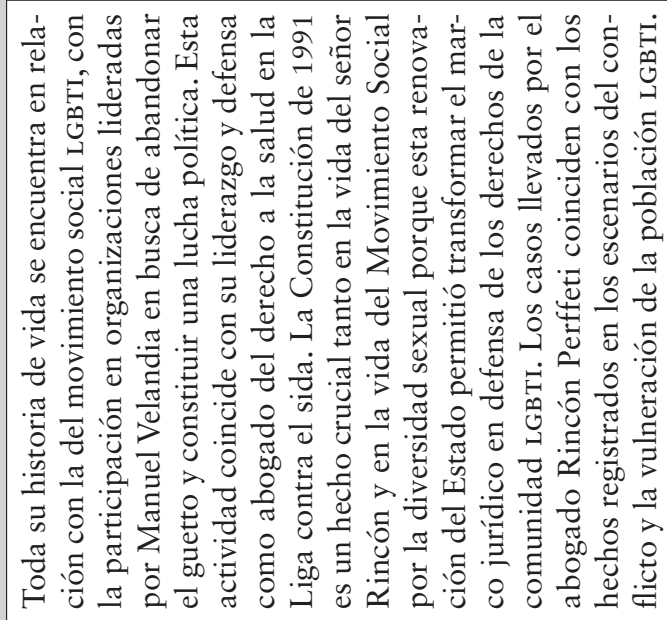 \\
\hline & & 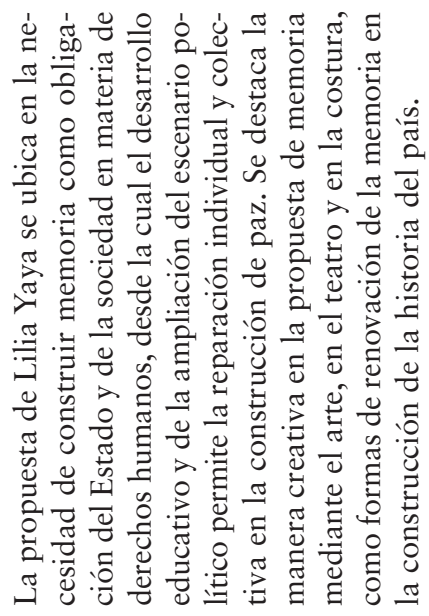 & & 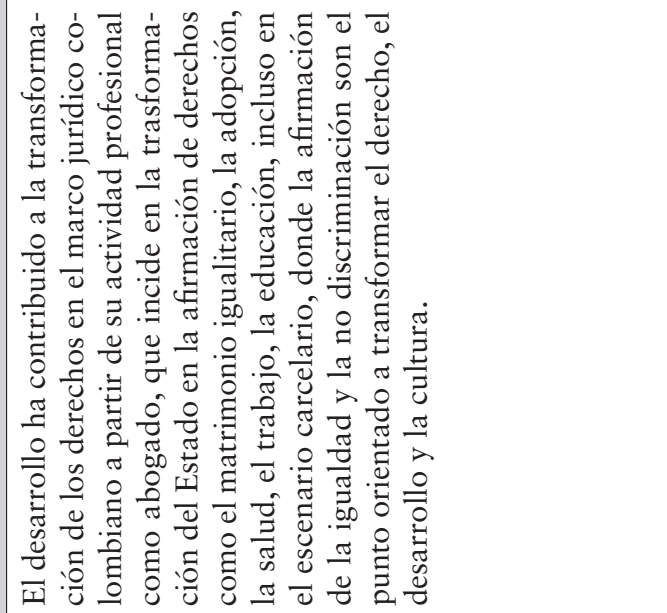 \\
\hline
\end{tabular}


